\title{
The lower bathyal and abyssal seafloor fauna of eastern Australia
}

T. D. O'Hara ${ }^{1 *}$ (D, A. Williams², S. T. Ahyong ${ }^{3}$, P. Alderslade ${ }^{2}$, T. Alvestad ${ }^{4}$, D. Bray ${ }^{1}$, I. Burghardt ${ }^{3}$, N. Budaeva ${ }^{4}$,

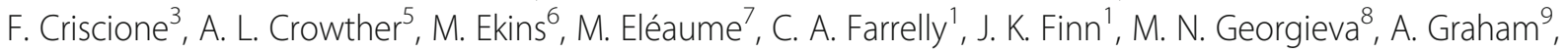
M. Gomon', K. Gowlett-Holmes², L. M. Gunton ${ }^{3}$, A. Hallan³ , A. M. Hosie ${ }^{10}$, P. Hutchings 3,11 , H. Kise ${ }^{12}$, F. Köhler ${ }^{3}$,

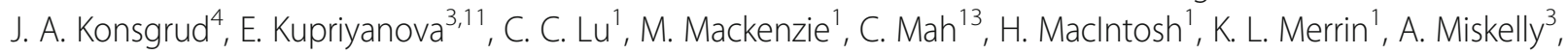
M. L. Mitchell ${ }^{1}$, K. Moore ${ }^{14}$, A. Murray ${ }^{3}$, P. M. O'Loughlin' ${ }^{1}$, H. Paxton ${ }^{3,11}$, J. J. Pogonoski ${ }^{9}$, D. Staples ${ }^{1}$, J. E. Watson ${ }^{1}$, R. S. Wilson ', J. Zhang ${ }^{3,15}$ and N. J. Bax ${ }^{2,16}$

\begin{abstract}
Background: Our knowledge of the benthic fauna at lower bathyal to abyssal (LBA, > $2000 \mathrm{~m}$ ) depths off Eastern Australia was very limited with only a few samples having been collected from these habitats over the last 150 years. In May-June 2017, the IN2017_V03 expedition of the RV Investigator sampled LBA benthic communities along the lower slope and abyss of Australia's eastern margin from off mid-Tasmania $\left(42^{\circ} \mathrm{S}\right)$ to the Coral Sea $\left(23^{\circ} \mathrm{S}\right)$, with particular emphasis on describing and analysing patterns of biodiversity that occur within a newly declared network of offshore marine parks.
\end{abstract}

Methods: The study design was to deploy a $4 \mathrm{~m}$ (metal) beam trawl and Brenke sled to collect samples on soft sediment substrata at the target seafloor depths of 2500 and $4000 \mathrm{~m}$ at every 1.5 degrees of latitude along the western boundary of the Tasman Sea from $42^{\circ}$ to $23^{\circ} \mathrm{S}$, traversing seven Australian Marine Parks.

Results: The biological sampling included 35 beam trawls, 28 Brenke sleds, 8 box cores, 20 surface meso-zooplankton tows, and 7 Deep Towed Camera transects. In total, 25,710 specimens were identified to 1084 taxonomic entities, including 847 species-level, 144 genus-level and 69 family-level and 24 higher-level taxa. Of the species-level taxa, only 457 were assigned species-level taxonomic names, which implies that up to $58 \%$ of the collected fauna is undescribed. In addition, the ranges of numerous species have been extended to include the western Tasman Sea.

Conclusions: The lower bathyal and abyssal fauna of soft sediment seafloors off eastern Australia has been systematically surveyed for the first time. The resultant collections will provide the foundation for much future ecological, biogeographical, phylogenetic and taxonomic research.

Keywords: Deep sea, Infauna, Epifauna, Taxonomy, Biodiversity, Biogeography, Australia, Tasman Sea

\section{Background}

Deep-sea ecosystems are one of the world's major ecological research frontiers, giving us new perspectives on macro-ecological questions (Danovaro et al. 2014). The deep sea is characterised by very cold water, extreme pressure, little to no light and limited food, with organic

\footnotetext{
*Correspondence: tohara@museum.vic.gov.au

${ }^{1}$ Museums Victoria, Melbourne, Australia

Full list of author information is available at the end of the article
}

matter residues sinking from surface waters or transported down continental margins (Rex and Etter 2010).

Our knowledge of the benthic fauna at lower bathyal to abyssal (LBA; > $2000 \mathrm{~m}$ ) depths off Eastern Australia is very limited, despite the presence of a large abyssal basin in the Tasman Sea. The H.M.S. Challenger (U.K.) took a single biological dredge sample (station 165, almost empty) in 1874 in $4754 \mathrm{~m}$ (Murray 1895). The Galathea expedition (Denmark) collected from 8 abyssal

(c) The Author(s). 2020 Open Access This article is licensed under a Creative Commons Attribution 4.0 International License, which permits use, sharing, adaptation, distribution and reproduction in any medium or format, as long as you give appropriate credit to the original author(s) and the source, provide a link to the Creative Commons licence, and indicate if changes were made. The images or other third party material in this article are included in the article's Creative Commons licence, unless indicated otherwise in a credit line to the material. If material is not included in the article's Creative Commons licence and your intended use is not permitted by statutory regulation or exceeds the permitted use, you will need to obtain permission directly from the copyright holder. To view a copy of this licence, visit http://creativecommons.org/licenses/by/4.0/.
} 
stations across the Tasman Sea in 1951-2 (Bruun 1957). Cruise 16 of the RV Dmitry Mendeleev (U.S.S.R.) trawled two abyssal samples from the Tasman Sea on its way across Southern Australia and up past Norfolk Island in 1975-1976. Finally, the RV Tangaroa (New Zealand) collected biological material at abyssal depths when searching for manganese nodules in 1982 on a transect between New Zealand and Sydney (Glasby et al. 1986). However, only three of these samples occurred within the Australian Exclusive Economic Zone (EEZ) and none from the newly created eastern network of Australian Marine Parks. Consequently, the composition of the LBA fauna of the western Tasman Sea was largely unknown.

The Tasman Basin formed 90-52 mya through the tectonic rifting of Australian and New Zealand continental masses (Gaina et al. 1998). It now extends from the Marion and Chesterfield plateaus off Queensland in the north $\left(24^{\circ} \mathrm{S}\right)$ to south of Tasmania $\left(48^{\circ} \mathrm{S}\right)$ before opening up into the Southern Ocean. A south-north spreading ridge formerly existed in the centre of the basin (Gaina et al. 1998). Subsequently, the north-south chain of Tasmantid seamounts were created along the Lord Howe Rise by the Australian plate moving over a crustal hotspot from 33.5-6.4 mya (Keene et al. 2008).

The upper continental slope along eastern Australia is broadly convex from the shelf break down to $1500 \mathrm{~m}$ (Keene et al. 2008). At mid slope depths (until $3000 \mathrm{~m}$ ) it is more concave, with the upper section sometimes forming an escarpment. On the lower slope there can be a series of steplike rocky ledges down to the abyssal plain at $4500-5000 \mathrm{~m}$. The margin is frequently dissected by canyons, some of which start at shelf depths (Huang et al. 2014), and slumps due to slope failure (Hubble et al. 2012). Sediment accumulates on the upper slope and sometimes on flatter surfaces at mid and lower slope depths where bottom currents are not too strong (Keene et al. 2008). The composition of the sediments is depth-dependent. Terrestrial siliceous and biogenic carbonate sediments occurring on the shelf and upper slope, and finer pelagic-derived sediments (mainly coccolith and foraminifera remains) on the lower slope and abyssal plain (Keene et al. 2008). Below the lysocline at $3600 \mathrm{~m}$, carbonate particles dissolve and sediments form a fine ooze (Martinez 1994).

There are two main current trajectories through the Tasman Sea according to depth (Tomczak and Godfrey 2003). The counter-clockwise southern Pacific gyre circulates shallow water from the Coral Sea, south along the Australian continental margin (East Australian Current) until about $32-35^{\circ} \mathrm{S}$ before heading eastward to northern New Zealand, although eddies move south as far as Tasmania (Ridgway and Dunn 2003). Antarctic Intermediate Water (AAIW) is present at $\sim 1000 \mathrm{~m}$, entering the Tasman Sea from two directions, one flowing from the south-west and the other from the north and east, the latter having become entrained by the surface gyre in the southern Pacific east of New Zealand. Both North Atlantic Deep Water (NADW) (at $2500 \mathrm{~m}$ ) and Antarctic Bottom Water (ABW) ( 4-5000 m) flow in from the south-west along the Australian margin, forming clockwise eddies at the northern end of the basin, with a net southern flow back down the Lord Howe Rise (Condie 1994; Tilburg et al. 2001). The northward flow of these deep currents is strong enough to remove sediment from the Australian lower continental slope leaving a rocky surface (Keene et al. 2008).

Oceanographic factors such as temperature, salinity and oxygen are relatively invariant within each water mass (Ridgway et al. 2002). ABW at $4000 \mathrm{~m}$ is relatively cold $\left(1.1^{\circ} \mathrm{C}\right)$, salty $(34.72 \%)$ and oxygenated $(4.49 \mathrm{ml} / \mathrm{l})$. NADW at $2500 \mathrm{~m}$ is slightly warmer $\left(1.9^{\circ} \mathrm{C}\right)$, the same salinity and slightly less oxygen $(4.13 \mathrm{ml} / \mathrm{l})$. AAIW at $1000 \mathrm{~m}$ is warmer again $\left(5.0^{\circ} \mathrm{C}\right)$, slightly less salty (34.47) and less oxygenated (4.06). There are no hypoxic $(\mathrm{O} 2<1.7 \mathrm{ml} / \mathrm{l})$ or anoxic $(<0.02)$ oxygen minimum zones in the Tasman Sea (Falkowski et al. 2011). The flux of particulate organic carbon (POC) to the seafloor varies with net primary production (NPP) in surface waters, seasonal variation in NPP (POC is increased if NPP is seasonal), and the depth of the seafloor (more POC gets consumed in the water column) (Lutz et al. 2007). Both NPP and seasonality of NPP is higher at southern latitudes in the Tasman Sea. Away from the coast, the waters of the northern Tasman Sea are oligotropic. While the sediments of the continental slope are well oxygenated and bioturbation is abundant, the carbon content of the sediments is less than 1\% (Keene et al. 2008), which is poor by global standards (Seiter et al. 2004).

In May-June 2017, the IN2017_V03 expedition of the RV Investigator sampled LBA benthic communities along the lower slope and abyss of Australia's eastern margin from off mid-Tasmania $\left(42^{\circ} \mathrm{S}\right)$ to the Coral Sea $\left(23^{\circ} \mathrm{S}\right)$, with particular emphasis on describing and analysing patterns of biodiversity that occur within a newly declared network of offshore marine parks (O'Hara et al. $2020 \mathrm{a}, \mathrm{b}$ ). This paper summarises the fauna collected by the expedition.

\section{Methods}

The study design was to deploy a $4 \mathrm{~m}$ (metal) beam trawl (Lewis 2010) and Brenke sled (Brenke 2005) to collect samples on soft sediment substrata at the target seafloor depths of 2500 and $4000 \mathrm{~m}$ at every 1.5 degrees of latitude along the western boundary of the Tasman Sea from $42^{\circ}$ to $23^{\circ} \mathrm{S}$, traversing seven Australian Marine Parks (AMPs) (Fig. 1). In addition, a few beam trawl 


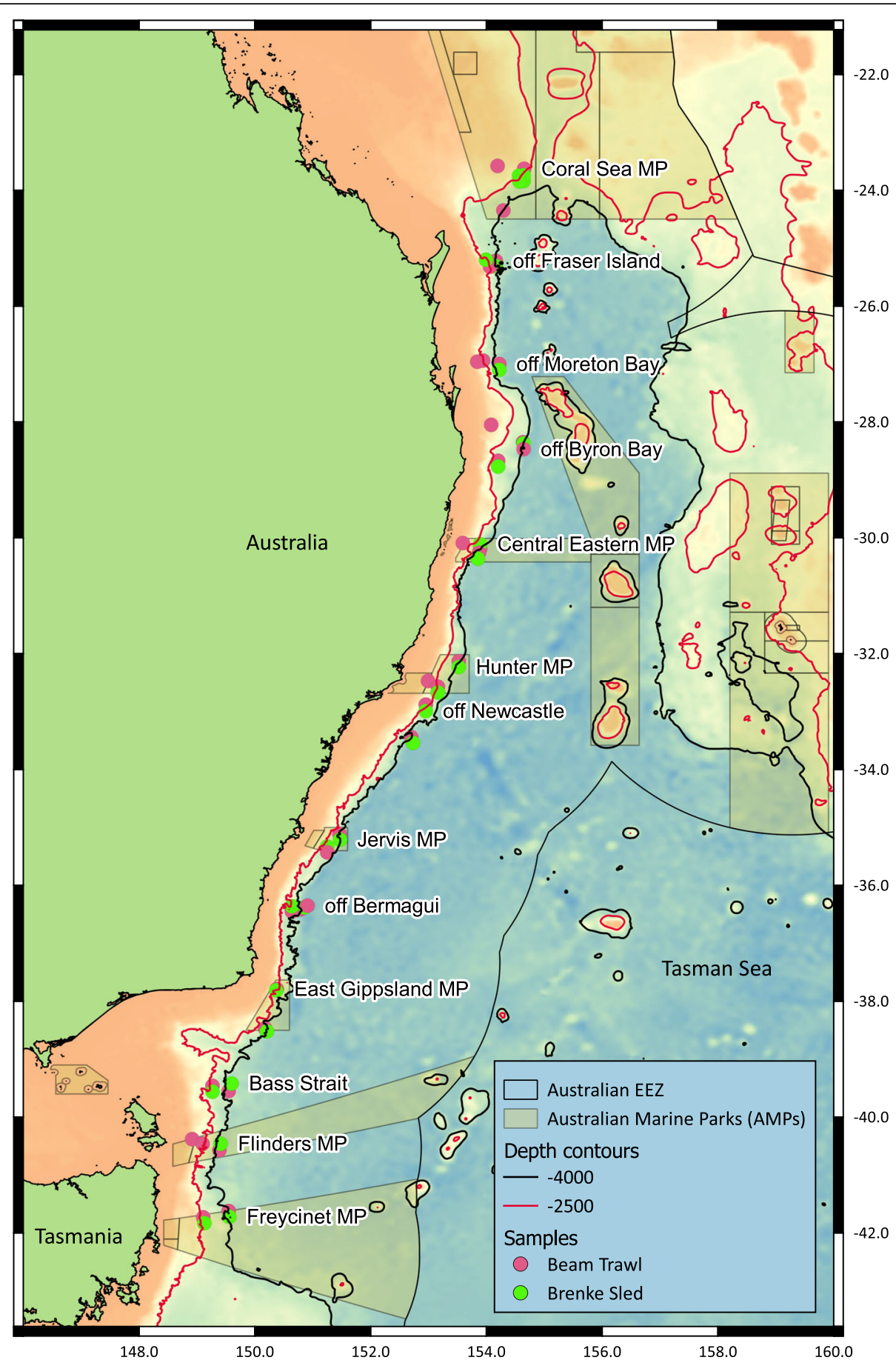

Fig. 1 Map of the eastern Australian continental margin showing the sample sites

samples were collected at $1000 \mathrm{~m}$ and a few box-corer samples at southern sites (until technical difficulties precluded its further use). A single deep-towed video transect $(1500-2500 \mathrm{~m})$ was completed within each Marine Park. Each site was mapped (bathymetry and backscatter) prior to deployment using a Kongsberg EM 122 multibeam sonar. Environmental data (temperature, salinity, pressure) were collected by a Sea-Bird SBE37SM sensor mounted on the Brenke Sled.

Samples were sorted, weighed and preserved (generally in $95 \%$ ethanol, the rest in formalin) on-board into broad taxonomic groups, and sent to taxonomic experts. The following groups of megafauna were subsequently identified to operational taxonomic units (OTUs, mostly 
to species, some to genus or family) and counted: sponges, hydroids, sea anemones and zooanthids, hexacorals and octocorals, barnacles, isopods, decapods, pycnogonids, annelids, echinoderms, molluscs, tunicates and fish.

Freshly collected material was photographed on-board the ship, predominantly by Karen Gowlett-Holmes (KGH, invertebrates), John Pogonoski (JP, fish), Alastair Graham (AG, fish), Jerome Mallefet (JM, general) and Robert Zugaro (RZ, general).

\section{Results}

The expedition biological sampling included 35 beam trawls, 28 Brenke sleds, 8 box cores, 20 surface mesozooplankton tows, and 7 Deep Towed Camera transects. Here we present results predominantly from the beam trawls and Brenke sleds (Fig. 1). The multibeam sonar revealed a continental slope topography that was much more complex and rugged than expected, with the margin incised by numerous canyons, sediment slumps, cliffs and other areas of exposed rock (Fig. 2). This complicated the placement and duration of sampling. The depth of the samples differed from the target as follows:

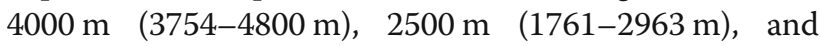
$1000 \mathrm{~m}$ (932-1257 m) (Tables 1 and 2). Sample 080 from $1225 \mathrm{~m}$ included a decaying manta ray with associated scavengers and predators. Sample 100 included a dead pilot whale skull and vertebrae which hosted Idas bivalves and Osedax worms (not previously reported from Australia).

In total to date, 25,710 specimens have been identified to 1084 taxonomic entities (Figs. 3, 4 and 5, Supplementary Table S1), including 847 species-level, 144 genuslevel and 69 family-level and 24 higher-level taxa. Twenty-nine species have been newly described from the survey. Of the species-level taxa, only 457 have been assigned species-level taxonomic names, which implies that up to $58 \%$ of the collected fauna is undescribed.

\section{Porifera}

\section{Ekins}

Over one hundred and twenty Porifera specimens were collected during the expedition, of which half were Demospongiae and half were Hexactinellida (the glass sponges). Of the Demospongiae, there were only four orders representing the four families of Ancorinidae, Polymastiidae, Niphatidae and Cladorhizidae. The Cladorhizidae (carnivorous sponges) were by far the most commonly collected family with 40 specimens, which is surprising considering that many of these species are only several millimetres in length.

Most notable from this expedition was the finding of 17 new species of carnivorous sponges, belonging to seven of the nine known genera of Cladorhizidae:
Abyssocladia, Asbestopluma, Chondrocladia, Cladorhiza, Lycopodina and Euchelipluma (Ekins et al. 2020). Also remarkable is that only two previously well-known carnivorous species were collected i.e. Chondrocladia clavata and Lycopodina calyx. Another commonly collected sponge was Radiella irregularis and two potential new species of Radiella. There was only one other Demospongiae sponge that could be identified to a described species Echinostylinos reticulatus, the remaining 22 OTUs of Demospongiae will be new to science.

The class Hexactinellida was represented by four orders, containing eight families in order of number of specimens found: Hyalonematidae, Pheronematidae, Rossellidae, Farreidae, Aulocalycidae, Euplectellidae and the Euretidae with the solitary species Pleurochorium cornutum. The most common glass sponges were the large Pheronema pilosum, Semperella schulzei, and the stunning Monorhaphis chuni, with its metre long glass spicules. Amongst the glass sponges there were another seven described species and 16 new species. Unfortunately all 11 specimens of the Farreidae are a Farreidae/ Euretidae incertae sedis, which has been repeatedly recovered from Australian and New Zealand seamounts as long dead fragments which cannot yet be assigned to a living species (Reiswig and Kelly 2011).

Overall this assemblage of sponges is to be expected from the Abyssal depths. It consists of glass sponges that have adapted to the 150 fold increase in silicon in the water and use it to create large glass structures, or those that have adapted to carnivory in an attempt to secure more reliable food resources. Many of the sponges collected on this expedition have been described from previous expeditions to the Pacific at Abyssal depths (Ridley and Dendy 1886, 1887; Lévi 1964, 1993; Koltun 1970). Interestingly there were no sponges collected on this expedition that matched to those previously collected from the Great Australian Bight (Sorokin et al. 2017; MacIntosh et al. 2018; Williams et al. 2018a; O'Hara et al. 2020a). Whilst more than half of the sponge specimens collected on this voyage are unknown, almost three quarters of the species are new. This indicates the high diversity of sponges on the abyssal plains and continental slopes that are still to be fully described.

\section{Hydrozoa \\ J.E Watson \& T.D. O'Hara}

Eight species of thecate hydroids (Leptothecata) were collected from depths of 1151-4173 m, including three previously known species (Acryptolaria angulata, Cryptolarella abyssicola, Zygophylax concinna), three newly described species (Hebella sp. nov, Amphisbetia sp. nov, Lytocarpia sp. nov) and two species (Hebella sp., Halecium sp.) which were too inadequate or in too poor a condition for identification (Watson 2019). 


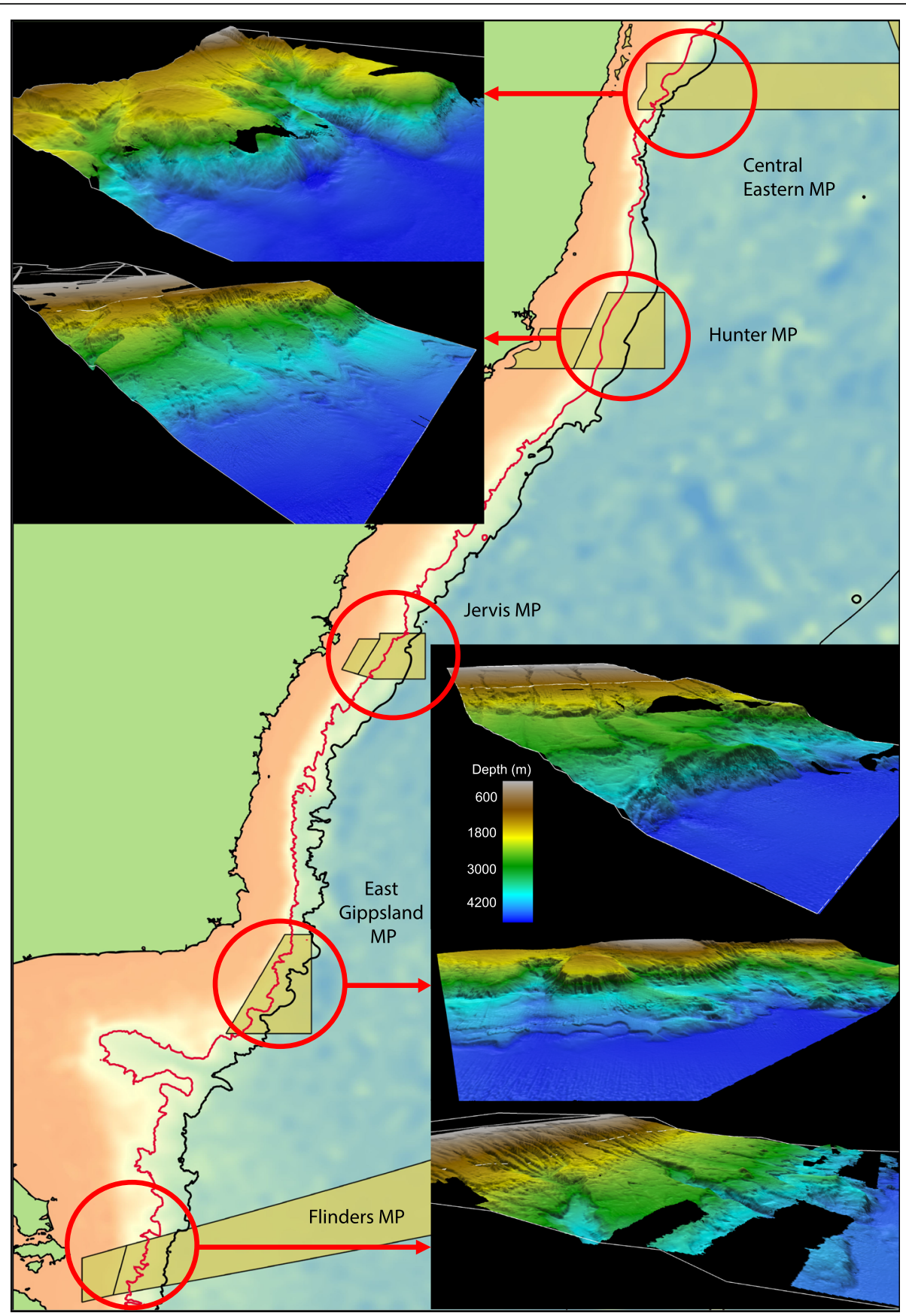

Fig. 2 Multibeam topology of five Marine Parks on the eastern Australian continental margin (map elements as Fig. 1)

Abyssal hydroids recorded from Challenger Station 160 from a depth of $4755 \mathrm{~m}$ were previously the only published reports of the abyssal hydroid fauna from Australia. They recorded two species, Cryptolarella abyssicola and Halisiphponia megalotheca (Allman 1888). Hydroids from the continental shelf have been reported from the Great Australian Bight (Bale 1914a, b, 1915; Watson 2018) and off New South Wales (Ritchie 1911).
None of these studies included material deeper than $100 \mathrm{~m}$.

Cryptolarella abyssicola was by far the most abundant species with 12 records. The species is a wide-ranging abyssal hydroid that has previously been recorded under various names from the Southern, Eastern Pacific and Atlantic Oceans in 2470-6328 m (Calder and Vervoort 1998; Marques et al. 2005). The Australian range of $C$. 
Table 1 Beam trawl sample location, depth, date

\begin{tabular}{|c|c|c|c|c|c|c|}
\hline Stn & Location & Lati-tude & Longi-tude & Mid depth (m) & Date $(\mathrm{d} / \mathrm{m} / \mathrm{y})$ & Area sampled $\left(\mathrm{m}^{2}\right)$ \\
\hline 004 & Freycinet MP & -41.731 & 149.120 & 2785 & $18 / 5 / 17$ & 29,584 \\
\hline 006 & Freycinet MP & -41.626 & 149.552 & 4037 & $18 / 5 / 17$ & 30,344 \\
\hline 013 & Flinders MP & -40.386 & 148.928 & 1041 & 20/5/17 & 7908 \\
\hline 014 & Flinders MP & -40.464 & 149.102 & 2392 & 20/5/17 & 15,348 \\
\hline 015 & Flinders MP & -40.473 & 149.397 & 4126 & 20/5/17 & 10,572 \\
\hline 022 & Bass Strait & -39.462 & 149.276 & 2726 & $22 / 5 / 17$ & 11,756 \\
\hline 030 & Bass Strait & -39.552 & 149.553 & 4165 & 23/5/17 & 29,312 \\
\hline 032 & East Gippsland MP & -38.479 & 150.184 & 3851 & $24 / 5 / 17$ & 11,580 \\
\hline 035 & East Gippsland MP & -37.792 & 150.382 & 2459 & $25 / 5 / 17$ & 15,352 \\
\hline 043 & Bermagui & -36.351 & 150.914 & 4800 & $27 / 5 / 17$ & 14,824 \\
\hline 044 & Bermagui & -36.355 & 150.644 & 2754 & $27 / 5 / 17$ & 17,972 \\
\hline 053 & Jervis MP & -35.114 & 151.469 & 3981 & 28/5/17 & 16,792 \\
\hline 056 & Jervis MP & -35.333 & 151.258 & 2643 & 29/5/17 & 15,976 \\
\hline 065 & Newcastle & -33.441 & 152.702 & 4226 & $30 / 5 / 17$ & 13,992 \\
\hline 067 & Newcastle & -32.985 & 152.952 & 2803 & $31 / 5 / 17$ & 19,748 \\
\hline 069 & Hunter MP & -32.479 & 152.994 & 1021 & $3 / 6 / 17$ & 12,508 \\
\hline 070 & Hunter MP & -32.575 & 153.162 & 2534 & $3 / 6 / 17$ & 26,260 \\
\hline 078 & Hunter MP & -32.138 & 153.527 & 4004 & $4 / 6 / 17$ & 19,608 \\
\hline 080 & Central Eastern MP & -30.099 & 153.596 & 1225 & $5 / 6 / 17$ & 16,096 \\
\hline 086 & Central Eastern MP & -30.098 & 153.899 & 2473 & $5 / 6 / 17$ & 13,384 \\
\hline 088 & Central Eastern MP & -30.264 & 153.870 & 4441 & $6 / 6 / 17$ & 18,328 \\
\hline 090 & Byron Bay & -28.677 & 154.203 & 2574 & $7 / 6 / 17$ & 15,400 \\
\hline 097 & Byron Bay & -28.355 & 154.636 & 3782 & $8 / 6 / 17$ & 27,508 \\
\hline 099 & Byron Bay & -28.371 & 154.649 & 3789 & $9 / 6 / 17$ & 14,416 \\
\hline 100 & Byron Bay & -28.054 & 154.083 & 1006 & $9 / 6 / 17$ & 18,968 \\
\hline 101 & Moreton Bay & -26.946 & 153.945 & 2548 & $9 / 6 / 17$ & 11,564 \\
\hline 102 & Moreton Bay & -27.008 & 154.223 & 4269 & $10 / 6 / 17$ & 18,332 \\
\hline 104 & Moreton Bay & -26.961 & 153.848 & 1104 & 10/6/17 & 13,352 \\
\hline 109 & Fraser Island & -25.221 & 154.164 & 4005 & $11 / 6 / 17$ & 18,156 \\
\hline 115 & Fraser Island & -25.325 & 154.068 & 2346 & $11 / 6 / 17$ & 11,976 \\
\hline 121 & Coral Sea MP & -23.587 & 154.194 & 1053 & 13/6/17 & 13,352 \\
\hline 122 & Coral Sea MP & -23.751 & 154.639 & 2349 & $13 / 6 / 17$ & 13,548 \\
\hline 128 & Coral Sea MP & -23.631 & 154.660 & 1765 & $13 / 6 / 17$ & 13,964 \\
\hline 135 & Coral Sea MP & -24.352 & 154.291 & 4001 & $15 / 6 / 17$ & 19,812 \\
\hline
\end{tabular}

abyssicola is now extended along the south-eastern Australian coast from cool temperate Tasmania in the south to the subtropical Coral Sea. Acryptolaria angulata has been found from deep water in the Indian Ocean, Indo-west Pacific, New Caledonia and New Zealand (Vervoort and Watson 2003). The two new records of Zygophylax concinna extends its range from the only known record found off Sydney (Ritchie 1911) and to the depth range of $100 \mathrm{~m}$ to $3754 \mathrm{~m}$.

Three new species occur in the collection from the genera Hebella, Amphisbetia and Lytocarpia. The first two were recovered from depths of $4133 \mathrm{~m}$ and $4131 \mathrm{~m}$ respectively from eastern Bass Strait, Victoria. Amphisbetia is a moderately common hydroid genus from shallow coastal environments of southern Australia (Watson 1973), so the record from $4131 \mathrm{~m}$ possibly indicates that it is a floating fragment from a shallow water colony entrained in the trawl net. With more material, the new species of Lytocarpia from the Coral Sea, may prove to be a diminutive subspecies of $L$. spiralis, a common deep water species from around New Zealand (Vervoort and Watson 2003). 
Table 2 Brenke Sled sample location, depth, date

\begin{tabular}{|c|c|c|c|c|c|c|}
\hline Stn & Location & Lati-tude & Longi-tude & Mid depth (m) & Date $(\mathrm{d} / \mathrm{m} / \mathrm{y})$ & Area sampled $\left(\mathrm{m}^{2}\right)$ \\
\hline 005 & Freycinet MP & -41.730 & 149.135 & 2784 & $18 / 05 / 17$ & 2985 \\
\hline 009 & Freycinet MP & -41.626 & 149.560 & 4028 & 19/05/17 & 4587 \\
\hline 016 & Flinders MP & -40.463 & 149.415 & 4130 & $21 / 05 / 17$ & 4753 \\
\hline 023 & Bass Strait & -39.462 & 149.277 & 2734 & $22 / 05 / 17$ & 2951 \\
\hline 031 & Bass Strait & -39.422 & 149.604 & 4160 & 23/05/17 & 3850 \\
\hline 033 & East Gippsland MP & -38.521 & 150.213 & 4085 & $24 / 05 / 17$ & 2872 \\
\hline 040 & East Gippsland MP & -37.815 & 150.373 & 2673 & 25/05/17 & 1724 \\
\hline 042 & off Bermagui & -36.385 & 150.863 & 4730 & $26 / 05 / 17$ & 5897 \\
\hline 045 & off Bermagui & -36.360 & 150.644 & 2787 & 27/05/17 & 4587 \\
\hline 054 & Jervis MP & -35.117 & 151.473 & 3953 & 28/05/17 & 2827 \\
\hline 055 & Jervis MP & -35.335 & 151.259 & 2666 & 28/05/17 & 4074 \\
\hline 066 & off Newcastle & -33.448 & 152.733 & 4286 & $30 / 05 / 17$ & 6193 \\
\hline 068 & off Newcastle & -32.993 & 152.957 & 2854 & $31 / 05 / 17$ & 3941 \\
\hline 076 & Hunter MP & -32.577 & 153.161 & 2507 & $3 / 06 / 17$ & 4548 \\
\hline 079 & Hunter MP & -32.131 & 153.527 & 4031 & 4/06/17 & 3909 \\
\hline 087 & Central Eastern MP & -30.113 & 153.898 & 2479 & $6 / 06 / 17$ & 3301 \\
\hline 089 & Central Eastern MP & -30.263 & 153.859 & 4425 & $6 / 06 / 17$ & 3550 \\
\hline 096 & off Byron Bay & -28.678 & 154.204 & 2578 & $7 / 06 / 17$ & 4909 \\
\hline 098 & off Byron Bay & -28.371 & 154.647 & 3782 & $8 / 06 / 17$ & 4324 \\
\hline 103 & off Moreton Bay & -27.000 & 154.223 & 4270 & 10/06/17 & 7426 \\
\hline 110 & off Fraser Island & -25.220 & 154.160 & 4007 & $11 / 06 / 17$ & 6648 \\
\hline 119 & off Fraser Island & -25.206 & 153.991 & 2308 & 12/06/17 & 3674 \\
\hline 123 & Coral Sea MP & -23.749 & 154.641 & 2305 & 13/06/17 & 4125 \\
\hline 131 & Coral Sea MP & -23.748 & 154.643 & 2327 & $14 / 06 / 17$ & 4975 \\
\hline 132 & Coral Sea MP & -23.756 & 154.568 & 2156 & 14/06/17 & 4296 \\
\hline 134 & Coral Sea MP & -23.750 & 154.572 & 2124 & $14 / 06 / 17$ & 4054 \\
\hline
\end{tabular}

There were surprisingly few species and few locality records in the collection considering the extensive latitudinal range of the survey. This may be an artefact of decrease in hydroid diversity with depth, the sampling gear used, or sampling of predominantly sedimentary substrates.

Several siphonophores we also collected, including the characteristic mushroom-shaped bracts (Just et al. 2014; O'Hara et al. 2016) of the benthic rhodaliid species Dendrogramma enigmatica from off Bermagui (operation 044) and in Jervis Marine Park (056) in $2650-2821 \mathrm{~m}$. small denuded rhodaliid pneumatophores were also found in operation 056 and off Byron Bay (090 and 100) which may or may not be Dendrogramma. The pelagic bluebottle Physalia utriculus was caught, probably from the sea surface, in an abyssal beam trawl sample (op 030) off eastern Bass Strait.

\section{Actiniaria and Corallimorpharia}

\section{M.L. Mitchell \& A.L. Crowther}

The IN2017_V03 expedition represents the first time we can compare the actiniarian faunal composition by depth and latitude along the Eastern Australian coast. The bathyal and abyssal Actiniaria fauna collected off the Eastern coast of Australia totalled 111 lots (325 specimens) from 29 operations across all latitude and depths. The mid-lower bathyal depths $(1500-3500 \mathrm{~m})$ contained the most lots (57 with 126 specimens). However, the highest number of specimens were collected from abyssal depths $(<3500 \mathrm{~m})$, with 34 lots (136 specimens). The remainder (20 lots, 63 specimens) were collected from the upper bathyal depths $(>1500 \mathrm{~m})$. Eleven lots of Corallimorpharia were also collected from mid-lower bathyal and abyssal depths, but not from upper bathyal depths. Corallimorpharians have not been identified lower than order. 

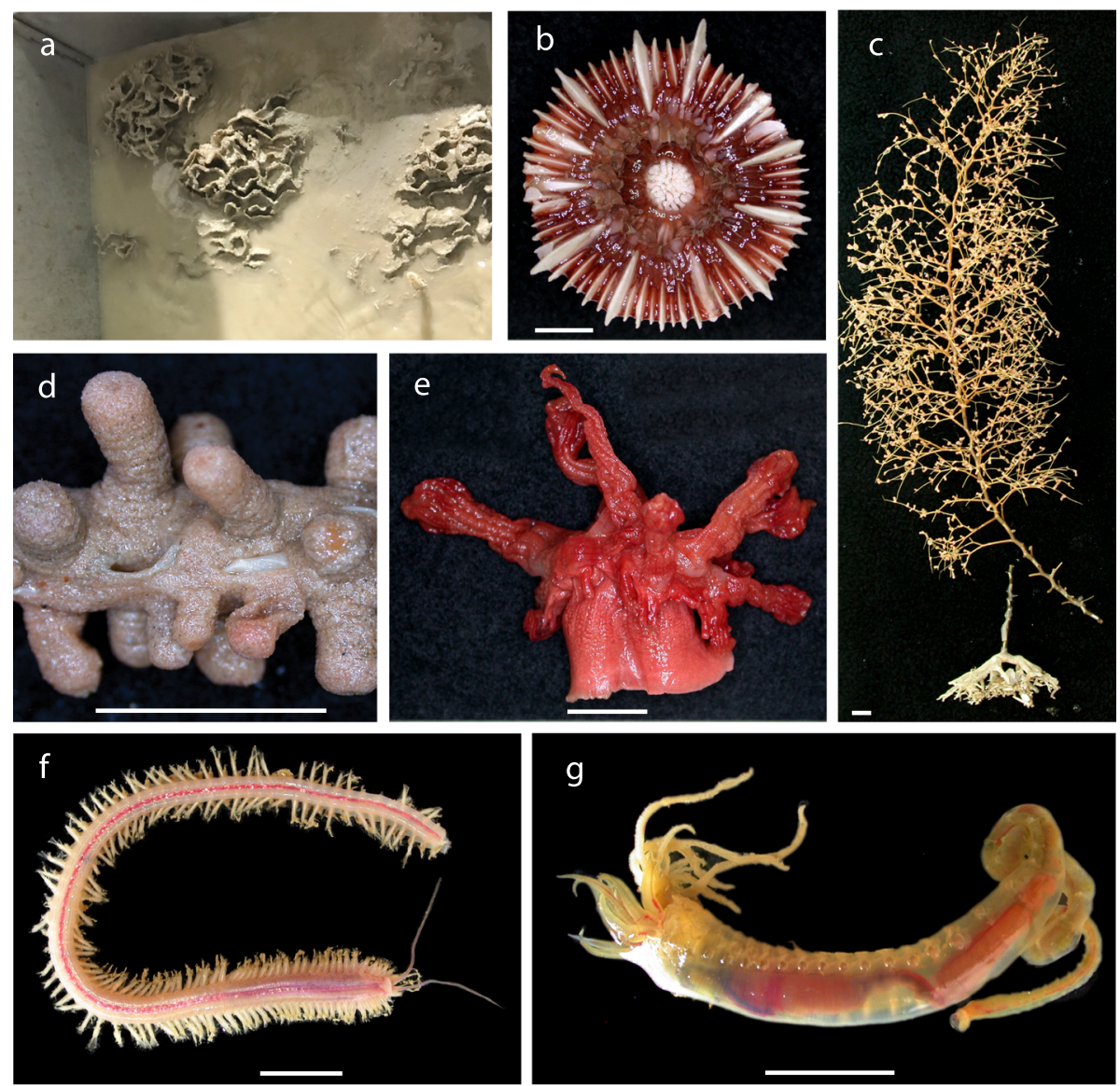

Fig. 3 Shipboard photographs of Porifera, Cnidaria and Annelida. a sponge ljimadictyum collected in a box core (op 011, 2393 m, JM); b cup coral Stephanocyathus coronatus (op 080, 1194-1257 m, KGH); c Chrysogorgia gorgonian (op 121, 1013-1093 m, KGH); d zoanthid in the family Parazoanthidae (sp; 1) (op 069, 1006-1036 m, KGH); e soft coral Anthomastus (op 003, 2948-2787 m, KGH); f sigalionid polychaete worm in the genus Neoleanira (op 080, 1194-1257 m, KGH); g melinnid polychaete in the genus Melinnopsis (op 056, 2650-2636 m, KGH). Scale bar = $1 \mathrm{~cm}$

Representatives of two families dominated all latitudes of the survey: Hormathiidae and Amphianthidae. These were also the only two families that were collected from the deepest $(4800 \mathrm{~m})$ to the shallowest operation (1006 $\mathrm{m})$.

Not surprisingly, representatives of Hormathiidae were sampled from all depths, and across the range of latitudes, with 49 lots (149 specimens) collected. Hormathiids are known to consistently dominate the actiniarian fauna catch of deep sea surveys (Fautin et al. 2013; MacIntosh et al. 2018), as shown here, with hormathiids not only being most sampled (149 specimens), but also the greatest diversity (12 OTUs), compared to other families. The Hormathiid Paracalliactis rosea was the most prevalent OTU (21 lots, 60 specimens), found in a wide range of latitudes. This species was not sampled from abyssal depths; however, the deepest collection from this survey $(>3000 \mathrm{~m})$ is similar to the depth this species was collected from in the Great Australian Bight (MacIntosh et al. 2018). Actinauge species were only represented in the lower latitudes of Bass Strait and Freycinet. The few specimens of Hormathiidae collected from abyssal depths were unable to be identified to genus at present.

Representatives of Amphianthidae (24 lots, 121 specimens) were collected from a wide range of depths (1000-4000 m), and throughout the extent of the latitudinal range sampled (Coral Sea MP to Freycinet MP). Specimens were identified to genera, representing eight OTUs; a similar diversity to that found in the Great Australian Bight. More work is needed to determine species identities and distribution. Unlike hormathiids, the Amphianthidae were found mostly at lower depths (> $2500 \mathrm{~m}$ ), and in greater numbers in the southern latitudes.

The Actinostolidae, another common faunal component of the deep sea, were found in far fewer numbers at shallower depths $<2500 \mathrm{~m}$. Actinostolids were lacking in many sites, although Sicyonis species were found in their greatest number near Freycinet. The remaining families; 

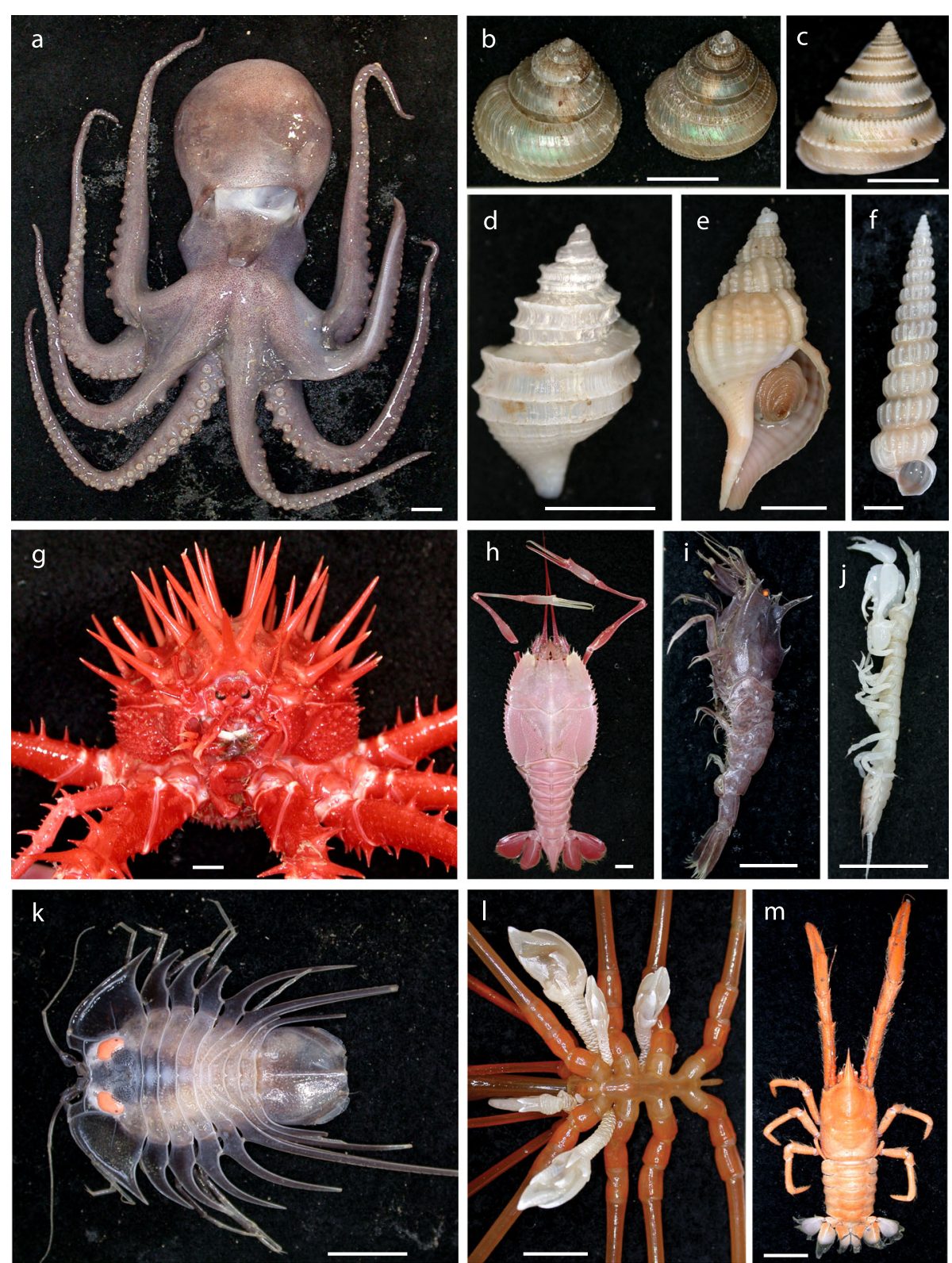

Fig. 4 Shipboard photographs of Mollusca and Arthropoda. a Muusoctopus (op 004, 2820-2751 m, KGH); b gastropod, Calliotropis (op 004, 28202751 m, KGH); c Calliotropis gastropod (op 069, 1006-1036 m, KGH); d raphitomid snail Phymorhynchus (op 015, 4114-4139 m, KGH); e ranellid snail (op 013, 932-1151 m, KGH); $\mathbf{f}$ small predatory wentle-trap sea snail Epitonium (op 069, 1006-1036 m, KGH); g spiny king crab Neolithodes bronwynae (op 035, 2338-2581 m, KGH); h widespread blind lobster Pentacheles laevis (op 069, 1006-1036 m, KGH); i deep-sea armoured shrimp Metacrangon (sp 1) (op 080, 1194-1257 m, KGH); j abyssal tanaid (op 006, 4022-4052 m, KGH); k serolid isopod Brucerolis victoriensis; I The barnacle Litoscalpellum, epibiont on the pycnogonid Colossendeis tasmanica (op 035, 2338-2581 m, KGH); $\mathbf{m}$ squat lobster Munidopsis kensleyi (op 121, 1013-1093 m, KGH). Scale bar $=1 \mathrm{~cm}$

Actiniidae, Actinoscyphiidae, Liponematidae and Sargartiidae were uncommon, and were represented by a single specimen in some instances. The actiniid Stylobates birtlesi was collected from one operation at $1000 \mathrm{~m}$, and this fits with the recorded depth range of the specimens but extends the distribution (Crowther et al. 2011). Previously, this was known only to occur off southern Queensland, and now from off Byron Bay in New South
Wales. From the limited representation of four families we are unable to make any inferences regarding faunal contribution via depth or latitude.

Of the specimens we were able to identify to species (Stylobates birtlesi, Paracalliactis rosea, and Monactis vestita), these new records provide a distribution expansion as indicated by the World Register of Marine species (WoRMS, see http://www.marinespecies.org/) and 

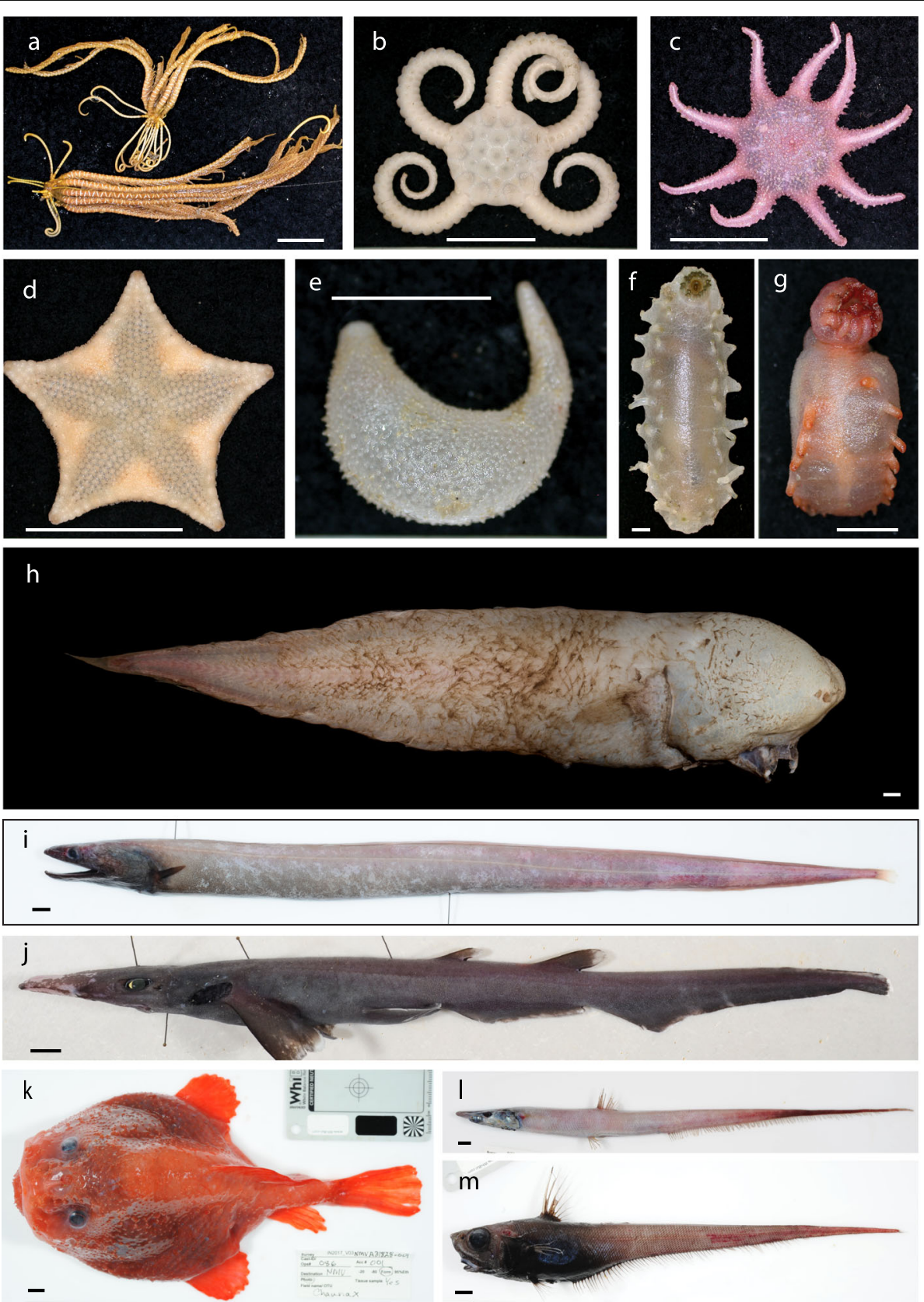

Fig. 5 Shipboard photographs of Echinodermata and Chordates. a the crinoid Thalassometra cf. gracilis (op 069, 1006-1036 m, KGH); b widespread abyssal brittlestar Amphiophiura bullata (op 015, 4114-4139 m, KGH); c multi-armed seastar Crossaster multispinus (op 069, 1006-1036 m, KGH); d sponge eating asteroid Hoplaster kupe (op 014, 2298-2486 m, KGH); e U-shaped holothurian Echinocucumis ampla has the mouth and anus protruding from the mud (op 035, 2338-2581 m, KGH); $\mathbf{f}$ holothurian Oneirophanta mutabilis (op 128, 1770-1761 m, KGH); $\mathbf{g}$ deposit feeding elasipod holothurian Amperima furcata (op 035, 2338-2581 m, KGH); h faceless cusk fish Typhlonus nasus (op 053, 3952-4011 m, RZ); i southern cut-throat eel Histiobranchus australis is widespread in southern oceans (op 056, 2650-2636 m, JP/AG); j pinocchio catshark, Apristurus australis (op 069, 1006-1036 m, JP/AG); k red coffin fish Chaunacops coloratus (op 086, 2429-2518 m, JP/AG); I allied halosaur, Aldrovandia affinis (op 069, 1006-1036 m, JP/AG); m kapala whiptail, Nezumia kapala (op 069, 1006-1036 m, JP/AG). Scale bar $=1 \mathrm{~cm}$

the Great Australian Bight sampling program (MacIntosh et al. 2018). Not unlike other deep-sea surveys, a proportion of samples (74\%) were taxonomically unresolved to species, genus or family, and eight OTU's could only be resolved to order level. These unresolved identifications may represent new species and distributions; this survey highlights the diversity of the abyssal actiniarian fauna present around Australia and our paucity of knowledge regarding their distribution by not only latitude, but depth as well. 


\section{Zoantharia}

\section{H. Kise}

Species of order Zoantharia are generally known as colonial sea anemones and are characterized by having two rows of tentacles and a unique bilateral arrangement of the mesenteries. Zoantharians can be found in a wide variety of marine environments (Fujii and Reimer 2013). Zoantharian taxonomy has been considered chaotic due to few diagnostic morphological characteristics and the presence of large amounts of intraspecific variation (Burnett et al. 1997; Reimer et al. 2004). However, molecular phylogenetic techniques have improved the taxonomy and systematics of zoantharians. As a result of previous studies using molecular phylogenetic techniques combined with morphological and ecological data, three families and 12 genera have been described since 2007 (e.g. Reimer et al. 2007, 2008; Fujii and Reimer 2011, 2013; Sinniger et al. 2013; Montenegro et al. 2015; Kise et al. 2019a).

In Australia, zoantharian diversity and taxonomy in shallow waters have been relatively well documented (see Haddon and Shackleton 1891; Burnett et al. 1995, 1997; Philipp and Fautin 2009). However, little or no information is focused on zoantharians in Australian deep-seas due to difficulty of collection. During RV Investigator expedition in 2017, 31 specimens were collected from the deep-seas of Australia. Molecular phylogenetic analyses combined with morphological observations showed that specimens collected from the Australian deep-sea contain 10 different morphological species. Kise et al. (2019b) formally described hermit crab-associated species Epizoanthus australis and E. gorgonus based on the specimens collected from Australian deep-seas. As well, echinoderm-associated species Epizoanthus sp. 1 is almost certainly an undescribed species.

Deep-sea zoantharians have recently attracted attention as there is apparently much undiscovered diversity (Reimer et al. 2007; Sinniger et al. 2013; Carreiro-Silva et al. 2017; Kise et al. 2018). In fact, several undescribed Epizoanthus species were found in this current study. Thus, investigation of deep-sea zoantharian diversity can contribute to a better understanding of the systematics and evolutionary history of zoantharians.

\section{Octocorallia}

\section{$P$. Alderslade \& K. Moore}

The collection yielded 540 octocoral specimens comprising 15 families across 2 orders (Alcyonacea \& Pennatulacea), and included 5 new genera and 15 new species. Because sampling was mostly on soft bottom habitat, pennatulids (sea pens) dominated, accounting for 396 specimens. With a cosmopolitan distribution, the most common abyssal sea pen is Umbellula and it was therefore not surprising that species of this genus represented about a third of the collection.
Of the 95 specimens of the sea pen Porcupinella, 63 were identified as the North Atlantic species P. profunda described by López-González and Williams (2011) from the Porcupine Abyssal Plain. In an earlier paper (Dolan 2008), similar specimens were described under the name Umbellula carpenteri, but two different colony forms were illustrated: one lot looking like $P$. profunda from the same original location, and one Umbellula-like lot from the South Indian Ocean showing a markedly curved rachis. López-González \& Williams synonymised the author's Porcupine Abyssal Plain samples with P. profunda but assigned her curved samples, whose main taxonomic feature was not well illustrated, to an unnamed species of the genus Umbellula. However, both colony forms are present in the material from our collection, and notably they were collected together from the same operations and with intermediate colony forms present, suggesting that they be treated as the same species (Fig. 6a, b).

Specimens of another species of sea pen, morphologically assignable to Umbellula, show traits that suggest it requires a new genus and a putative new family, which could probably accommodate other nominal species of Umbellula as well. A new species of Porcupinella is also present. There are 26 previous Australian records (GBIF) of the sea pen genus Kophobelemnon and of these only 6 have been identified to a species - $K$. macrospinosum. Of the 67 Kophobelemon specimens in our collection, nearly one third can be assigned to this species. The remainder represent one known and four new species.

A new species of the rare, small, encrusting soft coral Scyphopodium provides a new record for Australia and also a considerable range extension for the genus, only having been previously reported from Iceland and southern Africa. The uncommon genus Telestula is represented by 13 nominal species, but the literature is very inadequate and probably fewer than half of these species are valid. Our material contains 9 specimens comprising 3 unidentifiable species and a specimen of Telestula spicuola robusta previously only recorded from Hawaii. The collection of the gorgonian Acanella rigida is possibly only the third valid report of this species since it was first described from the Challenger expedition, and the first time recorded outside of Indonesia and the Philippines (Fig. 6c). A new genus of gorgonian from the Family Isididae, Subfamily Mopseinae, is also noteworthy for the attractive appearance of the polyp sclerites (Fig. 6d).

\section{Annelida}

L. M. Gunton, M. N. Georgieva, E. Kupriyanova, R. S. Wilson, H. Paxton, P. Hutchings, A. Murray, I. Burghardt, J. A.

Konsgrud, T. Alvestad, J. Zhang \& N. Budaeva

Over 6000 annelid specimens were recorded from combined bathyal and abyssal beam trawl, Brenke sled and box core samples (Gunton et al. submitted). Samples 

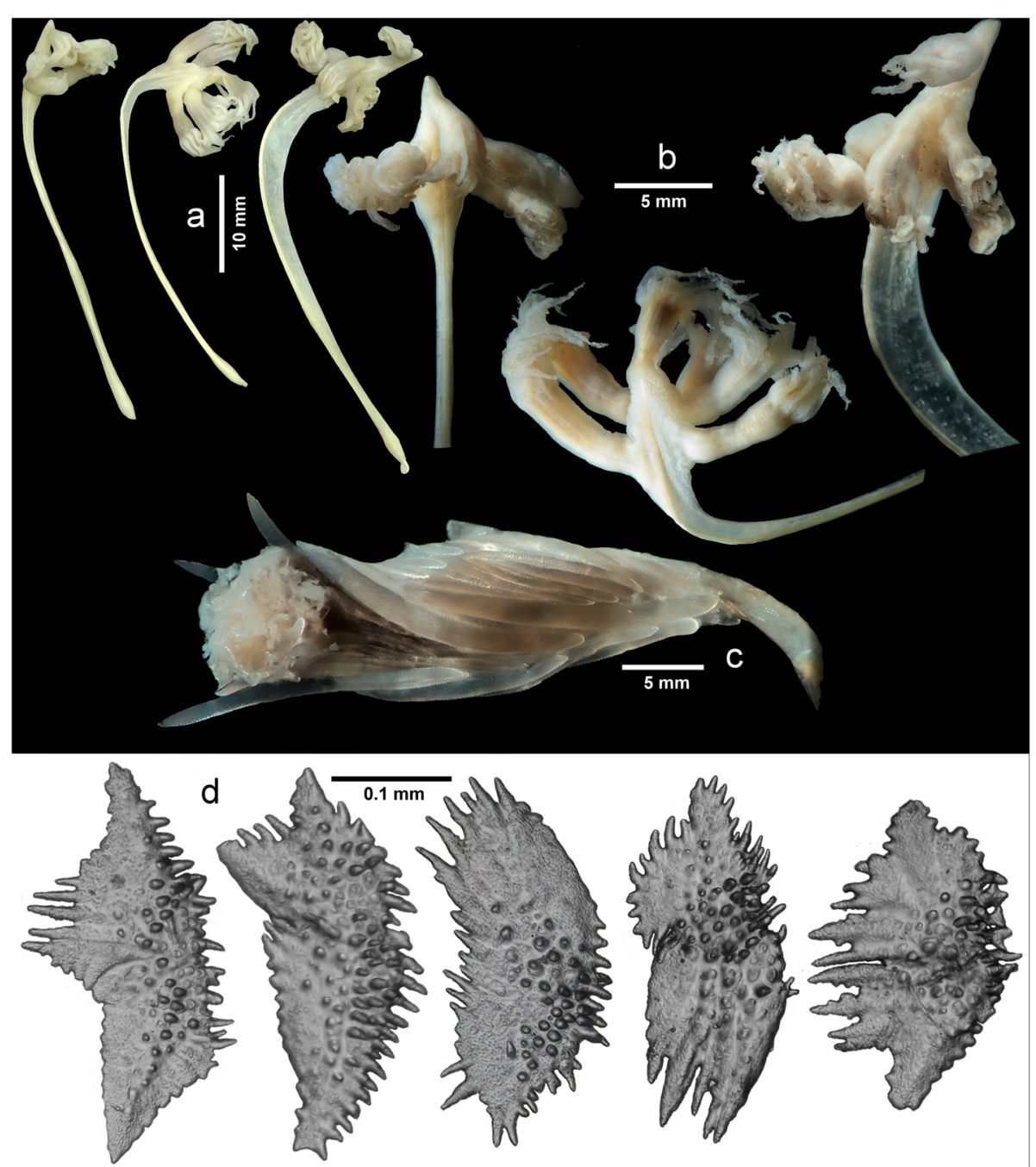

Fig. 6 Octocorallia. Porcupinella profunda a whole colonies and b polyp region; c Acanella rigida terminal polyp; d Isididae new genus, polyp body sclerites

included representatives of polychaetes, Sipuncula and Echiura. The polychaetes, the most abundant group (5800 individuals), were composed of 47 families and at least 205 species/OTUs. Serpulidae (908 individuals), Dorvilleidae (470), Sigalionidae (413), Aphroditidae (381) and Ampharetidae (342) were the most abundant polychaete families. These results are similar to those of the global abyssal polychaete fauna, where ampharetids made up $10 \%$ of the total number of polychaete species recorded below $2000 \mathrm{~m}$ depth and serpulids were also abundant (3\% total number of deep-sea species recorded) (Paterson et al. 2009). The families Ampharetidae and Serpulidae were also dominant in a large scale study of the deep Great Australian Bight (GAB) at 192$5032 \mathrm{~m}$ depth (MacIntosh et al. 2018). The high total abundance of serpulids in the beam trawl samples is mostly a result of operations 097 and 099 (around 3780 m) where the trawls retrieved numerous pebbles with calcareous tubes of serpulids (mainly Bathyvermilia $\mathrm{n}$. sp.) attached.

Our preliminary morphological examinations suggest that the most species-rich families were Polynoidae (17 species), Onuphidae (13), Serpulidae (12), Acrocirridae (10) and Maldanidae (10). Serpulidae, Onuphidae and Polynoidae also had a high species richness in the deep GAB along with the Spionidae, Cirratulidae, Syllidae and Paraonidae (MacIntosh et al. 2018). The most abundant species in this study were Bathyvermilia n. sp. (Serpulidae), and Laetmonice yarramba (Aphroditidae).

This study yielded around 188 annelid species that could not be designated a Latin binomial name and may be new to science ( $88 \%$ of a total 214 annelid species). To date, six species have been described: sabellariids 
Gesaia csiro and Phalacrostemma timoharai (Zhang et al. 2020), melinnids Melinnopsis chadwicki and M. gardelli (Gunton et al. 2020), and pectinariids Petta investigatoris and P. williamsonae (Zhang et al. 2019). The species currently being described include five onuphid species (Genus: Nothria), two ampharetids (Amage, Anobothrus) and four serpulids (Bathyvermilia, Hyglopomatus, Spriodiscus).

As this is the first dedicated study of Australian eastern abyssal fauna, a number of species have been reported for the first time in Australian waters and have geographic range extensions. A new species in the genus Myriowenia (Oweniidae) is reported from deep Australian waters, the genus having only been reported in Australia once before from $60 \mathrm{~m}$ off the coast of New South Wales (Capa et al. 2012). The genus Boguella (Maldanidae) is also reported for the first time in Australian waters. The abundant aphroditid scaleworm, Laetmonice yarramba, previously recorded from around Australia in 60-523 m depth (Hutchings and McRae 1993), has been recorded now from the deep GAB $(189-3884 \mathrm{~m})$ and from the present study in the lower bathyal and abyssal environments ranging from southern Queensland to Tasmania $(932-4800 \mathrm{~m})$. The wide geographic and bathymetric distribution, as well as its morphological variability, strongly suggest it is a species complex. Laetmonice yarramba is likely carnivorous, preying on both mobile macrobenthos, sessile foraminifera and carrion (Jumars et al. 2015), its large $(4-8 \mathrm{~cm})$ and robust body may increase the likelihood of its collection during beam trawl sampling methods. The sternaspid Sternaspis cf. annenkovae is reported from Australia, morphologically these specimens most resembled $S$. annenkovae, a species described from deep $(3980-4070 \mathrm{~m})$ waters in the north-western Pacific, however, genetically the Australian specimens were very similar to specimens identified as Sternaspis cf. williamsae collected from the deep north-western Pacific (Drennan et al. 2019).

During the beam trawl sampling operation 100 (depth 999-1013 m) the skull and vertebrae of a pilot whale (possibly Globicephala macrorhynchus) were collected, the first natural whale fall reported from Australian waters. A high abundance and diversity of annelids was associated with the whale bones. Annelids found on the bones included representatives of the typical 'bone-eating' Siboglinidae (Osedax n. spp.), numerous specimens of the dorvilleid Ophryotrocha, a genus that is often abundant and diverse at whale falls and other organically enriched habitats, as well as Orbiniidae, Phylodocidae (Eumida sp.) and Protodrilidae. A detailed study and description of the whale bone associated fauna is ongoing.

\section{Cirripedia \\ A.M. Hosie}

A total of 400 cirripede specimens were collected during the survey, comprising 5 families, 18 genera and 34 species/OTUs. The Scalpellidae was the most diverse family, represented by 24 species (143 specimens), however the Verruccidae was the most abundant family with 220 specimens collected (5 species). Gibbosaverruca navicula and Cristallinaverruca sp.1 were the most abundant species with 106 and 72 specimens collected, followed by Metaverruca recta with 28. More than half of the specimens of these species were collected in a single collecting event each, indicative of a patchy distribution within the survey area. Diversity was highest in depths less than $3000 \mathrm{~m}$ with 19 species exclusively collected in depths less than $3000 \mathrm{~m}$, compared with 7 found only at depths greater than $3000 \mathrm{~m}$.

The diversity and composition of taxa above species level are consistent with what is known of bathyal and abyssal barnacle fauna in Australia (Jones et al. 1990; MacIntosh et al. 2018). The species identified are largely wide-ranging in tropical and warm-temperate latitudes with only Arcoscalpellum cf. gryllum being a potential Australian endemic and two species, Teloscalpellum cf. gracile and Trianguloscalpellum hamulus, that are restricted to the Indo-Australian area. Significantly, only $13(38 \%)$ species are shared with those collected during the surveys of the eastern Great Australian Bight, the only other comparable collection of Australian deep sea barnacles (MacIntosh et al. 2018). These shared species demonstrate a connection between northern and southern areas of the Australian bathyal and abyssal zone.

Only one species, Litoscalpellum sp. nov., is considered to be new to science with any certainty, while the remaining OTUs will require further study of similar species. The newly recorded species for Australia, Arcoscalpellum cf. sculptum and Litoscalpellum crinitum, are range extensions south from tropical waters (Zevina 1981), while Neoscalpellum cf. crosnieri was previously known only from the western Indian Ocean (Young 2007).

The present collection contains many taxonomically valuable specimens, including good ontogenetic series for Amigdoscalpellum vitreum and Litoscalpellum sp. nov. This is of particular importance for genera such as Annandaleum, Litoscalpellum, Neoscalpellum that are characterised by significant ontogenetic shifts in the calcification of the capitular plates, making the identification of small numbers of specimens difficult, especially juveniles as these often are indistinguishable from other genera (Young 1990). The specimens will also be of value for phylogeographic studies as these specimens provide a wide geographic and latitudinal coverage that links the specimens collected from the Great Australian Bight to the deep seas of the tropical Indo-West Pacific. 


\section{Isopoda}

\section{K. L. Merrin}

The isopod collection consists of 4229 specimens from both beam trawl and Brenke sleds, all of which have been identified to family level, with $94 \%$ from the suborder Asellota. This high proportion of asellotes is expected at these depths (beyond $1000 \mathrm{~m}$ ) as this suborder is the dominant isopod group in these habitats.

In total, 27 families were identified. The Munnopsidae was the most commonly collected family, making up $39.8 \%$ of the total isopod numbers. The next most common family was the Ischnomesidae (14.6\%), followed by Desmosomatidae (13.2\%) and the Haploniscidae (11.4\%). The high prevalence of the Munnopsidae in these samples was not surprising as studies have found that this family is the most common family in the deep sea. In the north Pacific abyssal regions around the Kuril-Kamchatka Trench, Munnopsidae have made up around half of all isopod specimens collected, 53.9\% in Golovan et al. (2018) and $47.4 \%$ in Elsner et al. (2015), while in the Southern Ocean (Atlantic sector) Munnopsidae have made up 50\% of all isopod specimens (Brandt et al. 2007). In this study, the Ischnomesidae were the second highest in total isopod numbers, in contrast to other studies where the Desmosomatidae were the second most collected (Brandt et al. 2007; Elsner et al. 2015; Golovan et al. 2018). The most commonly collected non-asellote isopod was from the family Serolidae. There were 12 families who were represented by ten or less specimens.

In general, the Brenke sled samples collected from $4000 \mathrm{~m}$ showed more isopod diversity (in terms of families) than those from $2500 \mathrm{~m}$. There were only two nonasellote families, the Gnathiidae and Arcturidae that were collected from $4000 \mathrm{~m}$, all the other non-asellotes were restricted to depths of $2500 \mathrm{~m}$ and above.

All collected isopod families except one have been previously recorded from Australian waters (MacIntosh et al. 2018; pers. obs), however several have not had any species formally described from them. The family Urstylidae, which until now, has only been recorded from the Argentine Basin and the Clarion-Clipperton Fracture Zone (Riehl et al. 2014) was collected from off Bermagui at $4730 \mathrm{~m}$ (operation 042). No Serolidae were collected north of the Hunter region (operation 070).

\section{Decapoda}

\section{A. Farrelly \& S. T. Ahyong}

The IN2017_V03 survey of 1261 decapods comprised 31 families, 61 genera and 108 species, all from typical deep-water groups. Of these, 17 are new to science, 30 represent new records for the east coast of Australia and 15 for Australia as a whole (Ahyong 2019; Farrelly and Ahyong 2019). Significant extensions in depth ranges were also found for seven species (five dendrobranchiates, one caridean and one munidopsid).

Most new species from the voyage were from the Caridea (8\%) and Anomura (5.5\%). The highest number of new Australian records was in the Anomura and the highest number of new east coast records was in the Caridea (10\%). Six species from the ECA survey are endemic to Australia and five of these $(4.6 \%)$ are endemic to the east coast. The majority of species from the survey are widespread: $75 \%$ (81 species) have wider Indo-West Pacific ranges; $10 \%$ (11 species) have broader Southern Ocean or sub-Antarctic ranges and 28\% (30 species) are circumglobal, occurring in both the Atlantic and Indo-Pacific. Three species of hermit crab (Paguridae) represent new generic records for Australia: Catapaguroides microps, Chanopagurus atopos, and Icelopagurus crosnieri and three species of the brachyuran crab Ethusina (Ethusidae) are the first identified species of this family and genus recorded in Australia (Ahyong and Farrelly 2018).

The 15 new Australian records represent significant range extensions with most of the nearest previous records of these species from neighbouring Indo-West Pacific localities, including New Caledonia, Vanuatu, Wallis and Futuna Islands, and Indonesia, although several species were otherwise only found more distantly, including Taiwan (Chanopagurus atopos), the Philippines and the Bay of Bengal (Munidopsis arietina) (Baba et al. 2008). Other range extensions with more proximate previous records include Gordonella kensleyi, Glyphocrangon tasmanica, Neolithodes bronwynae and Munidopsis crassa, all previously known from the northeastern Tasman Sea; and Ethusina castro and E. rowdeni previously known from only a single specimen each from northeastern New Zealand (Ahyong 2008; Ahyong and Farrelly 2018). In addition, the survey extended the range of 30 species from adjacent regions to the north or south, or west from the Lord Howe Rise and Norfolk Ridge. Five species, previously known only from Western Australia were also recorded.

All of the undescribed species belong to genera already recorded from Australian waters, although their nearest congeners may not be Australian. For example, the nearest relatives of two new species of squat lobsters, Munida sp. and Munidopsis sp., occur farther afield in the Indo-West Pacific (Baba et al. 2008). Glyphocrangon cf. ferox, has its closest relative in Madagascar (Komai 2004) and Lebbeus sp. most closely resembles species from New Zealand and Hawaii (Rathbun 1906; Ahyong 2010).

Ninety-nine species (92\%) were found in the bathyal zone (1000-3500 m) with almost two-thirds (64) of these recorded between 1000 and $1500 \mathrm{~m}$. Twenty-three species $(21 \%)$ were collected from the abyss $(3500+\mathrm{m})$. This represents a decrease in diversity of $77 \%$ from 
bathyal to abyssal depths as 76 species fall out below $3500 \mathrm{~m}$. Fifteen species (65\% of abyssal species) were recorded from both bathyal and abyssal depths. Thirtythree species from the voyage were also recorded from the Great Australian Bight surveys (MacIntosh et al. 2018) with seven of these from abyssal depths. This degree of species overlap probably reflects the geographic proximity of the survey areas (i.e., eastern Australia and southern Australia, respectively) in combination with the southern flowing East Australian Current.

The Decapoda of the bathyal sea floor along the eastern coast was dominated numerically by deep-water hermit crabs (Parapaguridae; 37\%), followed by the deep-sea lobsters (Polychelidae) (10\%), squat lobsters (Munididae, Munidopsidae, Chirostylidae; 5\%) and a number of shrimp families (Mematocarcinidae, 8\%; Sergestidae, 6\%; Crangonidae, 5\%; Benthesicymidae, 5\%). Several families of brachyuran crabs were also recorded from bathyal depths (Cyclodorippidae, Cymonomidae, Homolidae, Ethusidae, Goneplacidae, Inachidae and Geryonidae), though most of these were from the $1000 \mathrm{~m}$ trawls. The abyssal fauna was dominated by the Nematocarcinidae (25\%), Crangonidae (20\%), Benthesicymidae (17\%), Munidopsidae (squat lobsters) (16\%), Acanthephyridae (10\%) and Aristeidae (4\%). Significantly fewer parapagurids, polychelids and sergestids were recorded at abyssal depths (all dominant at bathyal depths) and some groups such as the brachyurans, glyphocrangonids, chirostylids and pagurids were not recorded in any abyssal samples.

A marked increase in species diversity with decreasing latitudes was observed for sample sites close to $1000 \mathrm{~m}$ (18 species from the Hunter operations compared to 33 species from the Coral Sea). Many species were recorded from southern to northern operations but the largest number of brachyuran, anomuran and polychelid species was recorded from the northern operations from off Byron Bay and the Coral Sea. In contrast, the survey data of the lower bathyal waters $(1500-3500 \mathrm{~m})$ showed no pattern of increasing diversity with decreasing latitude (11 species from Freycinet, Tasmania, and 13 from the Coral Sea with various peaks of higher diversity in between). A latitudinal comparison of abyssal plain Decapoda also showed no increase in diversity from south to north, with four species recorded from Freycinet and three from the Coral Sea.

\section{Pycnogonida \\ D. Staples}

The IN2017_V03 collection is represented by 111 specimens assigned to 6 described species and 16 potentially new species. Seven species were collected using the Brenke Sled and 15 using the beam trawl. Only three species were recorded using both methods. Because the Brenke Sled has not been used elsewhere in Australian deep sea surveys comparison between regions can only be effectively based on the trawled material. It is apparent that had the Brenke Sled been used the number of Great Australian Bight (GAB) species could have been increased significantly. Without exception all Brenke Sled material consists of small, fine specimens that would easily go undetected amongst bulk collections associated with trawls and dredges. In this regard the Brenke Sled is a most effective collection method.

The most abundant and diverse genus represented in this collection is Colossendeis with 58 specimens belonging to 8 species. Colossendeis is a deep-sea genus that includes the largest pycnogonids, often with far-ranging distributions. Because of their size, with leg spans commonly ranging from 30 to $50 \mathrm{~cm}$ in Australian waters, Colossendeis is the most conspicuous genus represented in deep-sea trawls. Observations using ROV cameras of large specimens treading water or 'swimming' support the probability that distribution is assisted by slowmoving deep-sea currents whilst suspended in the water column. The most abundant species in this collection with 29 specimens is Colossendeis tasmanica recorded from 999 to $2939 \mathrm{~m}$ depth. This species is readily confused with $C$. colossea but differences are well supported morphologically and by (unpublished) molecular data. Colossendeis tasmanica is well represented in the GAB and probably in the NORFANZ collections as C. colossea. Colossendeis colossea is a pan-oceanic species recorded at depths of 420-5200 m worldwide and because of their similarities it is most likely that geographic and bathymetric records of the two species are confused.

A notable record in this collection is that of Ascorhynchus cooki. This species is one of seven rarely recorded 'giant' species in the genus. Nine specimens were collected from seven sites at depths $2336-2821 \mathrm{~m}$. This species has been collected previously from sites SW of Macquarie I., N of Chatham Rise and SE of Cook Strait at depths of 1463-2992 m. It was also collected on an RV Investigator trial voyage south of Tasmania at 2750 $m$ depth. It is likely that these specimens will enable the synonymy of this species with another, predominantly North Atlantic Ocean species, and if this is correct it will broaden the distribution considerably from the US east coast and the west coast of Africa. Shallow-water specimens of Ascorhynchus have been observed burrowing into the sand and it is suspected that grain size plays a part in their distribution. Based on morphological characteristics it can be assumed that a similar partial interstitial existence is shared by deep-water forms such as $A$. cooki. This species is also represented in GAB collections. Nine post-larval specimens found attached to feeding tentacles of the bentho-pelagic holothuroid Psychropotes are suspected to be this species. These specimens represent more than one stage of development but 
the most mature forms are beginning to develop characteristics of $A$. cooki and are suspected to be this species. Hitching a ride on a bentho-pelagic holothuroid not only broadens the spread of the species gene pool but assists settlement on fine sediments which accommodate both the feeding of the holothuroid and the burrowing of the pycnogonid. Presumably the fine sediments also support the food source of the adult pycnogonid. The holothuroid was collected by beam trawl at Jervis MP at $2636 \mathrm{~m}$ depth.

The record of Nymphon trituberculatum is only the second for this species and the first female specimen. The type locality for this species is recorded as the 'Great Australian Bight' but the coordinates given for

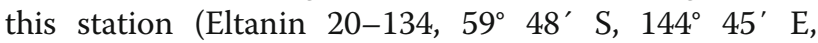
$3200-3259 \mathrm{~m})$ are on the Southeast Indian Ridge. The finding of this species along Australian eastern coast raises the possibility that the incorrect Eltanin station data has been assigned to the type locality.

\section{Bivalvia \\ H. Maclntosh}

The bivalve fauna consisted of 218 lots with a total of 1563 specimens, comprising 21 families, 33 genera and 59 species. All families and genera of bivalves collected were known from bathyal to abyssal environments, and overall patterns of abundance and diversity match reported trends from other deep sea regions (Knudsen 1970; Allen 2008; Kamenev 2017). While there are few deep water collections from eastern Australian to make reference to, affinities could be seen with the deep-sea bivalve fauna of neighbouring regions. The southern operations (South of Newcastle) showed considerable overlap with bivalves from the deep Great Australian Bight (MacIntosh et al. 2018). North of Newcastle and into the Coral Sea, the fauna resembled that collected in the waters around New Caledonia (Dijkstra 1994; Poutiers and Bernard 1995).

Almost half of the specimens recovered $(n=718,46 \%)$ were from three common, near-cosmopolitan deep-sea species: Bentharca asperula (Arcidae, $n=147$ ), Propeamussium meridonale (Propeamussiidae, $n=226$ ) and Abra profundorum (Semelidae, $n=345$ ). These three species were found in small numbers across multiple sites, but occasionally occurred in high abundances: $B$. asperula $n=103$ in trawl 102, $P$. meridonale $n=153$ in trawl 053 and $A$. profundorum $n=136$ in trawl 065 . Most other species were rare or sparsely distributed, with over a quarter of species $(n=16,27 \%)$ known only from single specimens; almost half $(n=25,42 \%)$ were found only at single sites.

It is interesting to note these three species all exemplify adaptations of suspension-feeding bivalves to deepsea conditions, where plankton is scarce. Abra profundorum is primarily a deposit feeder and employs its ctenidia for particle sorting (Allen and Sanders 1966). Propeamussium meridonale retains filamentous gills but has secondarily evolved carnivorous feeding, closing its valves on small prey items (Morton and Thurston 1989). Bentharca asperula remains a suspension feeder and instead shows adaptations to cope with the paucity of food, including enlarging the ctenidia and lowering metabolic rates (Oliver and Allen 1980).

The Protobranchia are primitive bivalves characterised by simple ctenidia and the presence of palps for depositfeeding. This mode of feeding is well suited to deep-sea soft sediments and protobranchs are often the dominant bivalve fauna in abyssal environments (Allen 1979). Here 16 species of protobranchs were recorded, including representatives of the Sareptidae, Siliculidae and Yoldiidae, poorly known in Australian waters. Significantly more protobranch species were recovered in this survey compared to surveys in southern Australia (MacIntosh et al. 2018), likely due to the use of use of Brenke sleds here, which captured more small infauna than beam trawls.

Carnivory is also common in deep-sea bivalves. In 'septibranch' bivalves, the gill filaments are fused into a single muscular septum. This diaphragm-like structure, coupled with a large, sensitive inhalant siphon allows septibranchs to rapidly inhale prey like small crustaceans and larvae (Morton 1981, 1987). Notable septibranchs recovered include the spectacularly sculptured Spinosipella costeminens (Verticordiidae) an unknown species of Halonympha (Halonymphidae), and two species of Cetoconcha (Cetoconchidae). These latter two genera have been previously split from larger families (Cuspidariidae and Poromyidae respectively) on the basis of small morphological characters, and fresh genetic material collected here may allow testing the monophyly of these groupings.

The beam trawls and brenke sleds targeted soft sediment substrates, but in several operations wood and whale bone were serendipitously recovered. These organic falls serve as islands amongst the ooze and host their own unique deep-sea fauna (Smith et al. 2015). Associated with whale and fish bones, two species of bathymodioline mussels in the genus Idas sp. could be separated on the basis of shell morphology and internal musculature. Identifications of these are tentative, however, as the taxonomy of the Bathymodiolinae is in a state of flux, with genetic studies revealing many cryptic species (Lorion et al. 2010; Thubaut et al. 2013).

Woody debris was recovered at several sites, hosting three species of Xylophagaidae. These bivalves are obligate wood-borers, the deep sea counterpart of the shallow-water Teredinidae, or "shipworms". Both burrow into wood with specially-modified shell valves and derive nutrition from with the aid of symbiotic, cellulose- 
digesting bacteria (Knudsen 1961; Distel et al. 2011). Like many deep-water taxa, the diversity of Xylophagaidae in Australian waters remains largely unknown.

\section{Gastropoda}

\section{F. Köhler, F. Criscione \& A. Hallan}

In all, 291 lots of Gastropoda were retrieved from the sampled bathyal to abyssal environments along the eastern Australian coast, containing 963 individuals. Altogether, these lots represented 136 species or morphologically distinguishable OTUs from at least 88 genera and 45 families. Only 15 species have so far been assigned an available taxonomic name. One species, Bouchetispira ponderi, has been formally described from this survey in the previously monotypic family Bouchetispiridae (Hallan et al. 2020). While many other OTUs have remained tentatively identified to genus- or species level, there is no doubt that several of these yet unidentified OTUs will eventually be assigned with an available species name pending further consultation with experts for various gastropod groups. Nonetheless, a significant proportion of the sampled gastropod fauna is considered to be new to science. For example, we consider the vast majority of the 44 OTUs in the family Raphitomidae (Neogastropoda: Conoidea) as undescribed. With regards to the numbers of collected individuals, the most abundant species were representatives of the families Abyssochrysidae, Eucychlidae, Mangeliidae, Philinidae and Turritellidae. The systematically most diverse family is the Raphitomidae (Conoidea), accounting for nearly one third of all gastropod species.

Our identifications have revealed high rates of bathymetric turnover with little overlap between species present at different depths. We have distinguished 27 species/OTUs among samples collected at about $1000 \mathrm{~m}$, 79 at about $2500 \mathrm{~m}$, and 40 at about $4000-4800 \mathrm{~m}$ depth. Among these, fewer than 20 species have been collected in more than one depth layer. The highest species diversity was generally recorded at mid- to lower bathyal depths of around $2500 \mathrm{~m}$. Here, we also observed a noticeable decrease in the sampled species diversity along a south-to-north gradient.

The bathyal and abyssal gastropod fauna of Australia has remained poorly documented and few deep water collections are available for a faunal comparison. We recorded some overlap with the fauna of the Great Australian Bight as reported by MacIntosh et al. (2018) particularly at the southernmost sampling sites. Several species have been recorded from both areas, the eastern Australian Abyss and the Great Australian Bight, such as Bathytoma agnata (Borsoniidae), Oocorys sulcata (Cassidae), Calliotropis carinata and C. canaliculata (Eucyclidae), Enixotrophon carduelis (Muricidae), Tritia ephamilla (Nassariidae), and Globiscala cf. boaespei (Epitoniidae). In addition, nine putatively undescribed species retrieved from the eastern Australian abyss were also reported from the Great Australian Bight. Of these, four belong to the Conoidea, the by far most diverse gastropod superfamily. However, for the majority of species/OTUs, no overlap has been recorded between the eastern Australian abyss and the Great Australian Bight. This observation may be indicative of considerable regional endemism in the gastropod fauna of the Australian deep sea.

The gastropods sampled during the eastern Australian voyage of the RV Investigator represent altogether six ecological feeding guilds, with predators comprising the vast majority of species, largely belonging to the order Neogastropoda. In addition, deposit-feeders, grazers and parasites were each about equally represented in terms of species numbers, while suspension feeders (Calliostomatidae and Turritellidae) and scavengers (Nassariidae) were the least diverse guilds (four species overall).

The majority of samples and species were collected by beam trawls while the Brenke sledge sampled comparatively few gastropods of small size, which would otherwise slip through the mesh of the beam trawl. Because of the overall low numbers of smaller gastropods in the size range of under $10 \mathrm{~mm}$, we consider the smallersized gastropod fauna as under-sampled owing to the specific limitations of the deployed collecting gear.

General patterns of diversity as here described for the gastropods of the eastern Australian abyss are consistent with faunal patterns described for other regions of the world. A high proportion of undescribed species-level diversity has also been recorded in deep-sea surveys in New Caledonia (Bouchet et al. 2008). Similarly, conoideans are frequently found to dominate marine gastropod faunas from the intertidal to abyssal depths, including the deepsea in New Caledonia (Bouchet et al. 2008).

The observed turnover in species composition across depth layers has also been observed for other gastropod faunas. For the northern Atlantic, a three-layered faunal composition has traditionally been described consisting of a shelf fauna (to about $300 \mathrm{~m}$ depth), a slope to bathyal fauna (to about $2500 \mathrm{~m}$ depth), and an abyssal fauna (extending to about $6000 \mathrm{~m}$ depth). However, in tropical waters a more frequent turnover between faunal assemblages at additional depth layers between about 200 and $1500 \mathrm{~m}$ depth has been reported (Bouchet et al. 2008).

Some notable differences have been observed in comparison with the gastropod fauna of the Southern Ocean where a steep decrease in species diversity has been reported with increasing depth (Brandt et al. 2009). Brandt et al. (2009) reported that species numbers dropped to around 20 species at depths below 
$1200 \mathrm{~m}$, whereas we recorded significantly higher cumulative species numbers at depths of $2500 \mathrm{~m}$ and even $4000 \mathrm{~m}$ across the eastern Australian continental margin.

\section{Cephalopoda}

\section{J. K. Finn \& C. C. Lu}

A total of 15 cephalopod specimens were collected in beam trawls over the course of this survey. These specimens represent 4 families and at least 6 species. While the total number of cephalopods collected is quite low, this survey increased the known distribution of multiple species and included at least one new record for Australia.

The majority of specimens collected during this survey were deep-water cirrate octopods, family Opisthoteuthidae. Six specimens of Opistoteuthis pluto, were collected at operations $022,080,100$ and 121 . While previously reported to occupy a distribution including the continental slope waters from the Great Barrier Reef to Tasmania ( $\mathrm{Lu}$ and Dunning 1998), this survey increased the known maximum depth for this primarily benthic species from 1254 $\mathrm{m}$ (Lu and Dunning 1998) to at least $2692 \mathrm{~m}$.

Among the cirrate octopods, the most well-known are the Dumbo Octopuses (genus Grimpoteuthis), nicknamed on account of their large fins, and deemed by some to resemble the ears of Disney's Dumbo the Flying Elephant. This survey provided the first record of Grimpoteuthis from Australian waters. Two specimens of Grimpoteuthis were collected at operations 035 and 044. Both specimens were found to be consistent with Grimpoteuthis abyssicola, described from a single specimen collected at $3180-3154 \mathrm{~m}$ on the adjacent slope (3535.1'S 16057.1'E) (O’Shea 1999).

The next most numerous taxa collected during this survey were the deep-water incirrate octopuses, Muusoctopus spp. (family Enteroctopodidae). Four specimens of Muusoctopus spp. were collected at operations 004 (2820-2751 m), 080 (1257-1194 m) and 100 (999-1013 $\mathrm{m})$, including a large specimen with a mantle length of approximately $180 \mathrm{~mm}$. Historically these octopuses have been treated under the invalid name Benthoctopus (e.g. Lu 2001). Gleadall et al. (2010) proposed Muusoctopus as a replacement name. The specimens collected during this survey will be invaluable to a much-needed review of the deep-water octopods of Australian waters.

Single representatives of two oegopsid squid species (family Mastigoteuthidae) were collected in beam trawls during this survey.

Mastigoteuthis psychrophila is a deep-water mesobathypelagic squid distributed circumpolarly throughout the Antarctic (Nesis 1977). A single specimen of Mastigoteuthis psychrophila was collected in a beam trawl in the Freycinet CMR off eastern Tasmania (operation
004). This specimen represents the most northerly confirmed record of this species, and potentially the deepest. On reporting the catches of the Dmitry Mendeleev in subantarctic and Antarctic waters, Nesis (1977) noted that, while the depth of $M$. psychrophila varied with latitude, the species occupied water with consistent hydrological conditions. While in the south specimens were collected at $500 \mathrm{~m}$, and in the north at $1500 \mathrm{~m}$, all specimens were encountered in water with a temperature approximately $2.1^{\circ} \mathrm{C}$, salinity approximately $34.7 \%$ and an oxygen content of about $5 \mathrm{ml} / \mathrm{l}$. The beam trawl specimen collected during this survey appears to be consistent with this latitude/depth trend, being encountered both further north and deeper than the material reported by Nesis (1977). While some doubt exists as to the actual collection depth of this specimen (as it was collected in an open beam trawl and hence may have been caught while the gear was descending or ascending), interestingly the hydrological conditions of the operation closely match those reported by Nesis (1977) as suitable for this species: temperature $1.8^{\circ} \mathrm{C}$, salinity $34.7 \%$, oxygen $4.3 \mathrm{ml} / \mathrm{l}$. While not officially detailed in this report, an additional specimen of $M$. psychrophila was collected in a demersal fish trawl in the early stages of this survey $\left(41^{\circ} 37.608^{\prime} \mathrm{S}, 149^{\circ} 8.958^{\prime} \mathrm{E}\right.$; NMV F245709). The northerly locations of these records are consistent with catches at similar latitudes in New Zealand (Braid and Bolstad 2015) and the suspicion that M. psychrophila may exist to approximately $40^{\circ} \mathrm{S}$ in the Atlantic (Young 2017).

The second mastigoteuthid squid collected during this survey was an Idioteuthis cordiformis. While previously reported from the survey region (Lu 2001) and sampled depth (Roper and Jereb 2010), the most notable aspect of this specimen (in relation to the survey) is its size. With a mantle length of $270 \mathrm{~mm}$, this specimen is the largest squid collected during this survey. Idioteuthis cordiformis is however reported to be the largest of all mastigoteuthid squids, attaining mantle lengths to $1000 \mathrm{~mm}$ (Young 2017).

During this survey a single sepiolid of the genus Heteroteuthis was collected. While eastern Australian records have historically been referred to as Heteroteuthis serventyi (e.g. (Lu 2001)), and more recently $H$. dagamensis (see Vecchione et al. 2013), a recent report of $H$. hawaiiensis from southern Australia (MacIntosh et al. 2018) highlights the need for a thorough review of this genus from Australian water. It is anticipated that the collected specimen will aid this review.

\section{Crinoidea \\ M. Eléaume}

In total 498 specimens of crinoid were collected during the 2017 expedition. One deployment only accounted 
for 402 specimens. Other deployments yielded from 1 to 20 specimens. These specimens represented at least 7 different species for which only tentative identifications are given: Adelatelecrinus cf. vallatus, Bathycrinus cf. australocrucis, Democrinus cf. japonicus, Monachocrinus cf. aotearoa, Pentametrocrinus cf. semperi, Thalassometra cf. gracilis and an unidentified representative of the feather star family Antedonidae.

Most of these species were collected in small numbers except Thalassometra and Democrinus. Both were collected in large numbers during operation 069, and this station may represent the optimal habitat for these two species. Adelatelecrinus, Pentametrocrinus and Democrinus were all restricted to depths from 1000 to 2000 . Thalassometra was collected mainly from depths around 1000 with some occurrences to $2500 \mathrm{~m}$ (Operation 086). Monachocrinus was collected at depths exceeding 2500 $\mathrm{m}$ and also at depths around $4000 \mathrm{~m}$. Some Bourgueticrinina occurrences, collected at intermediate depths once attributed to a species may help bridge this gap. Adelatelecrinus, Pentametrocrinus, Democrinus, Thalassometra and unidentified Antedonidae, were collected from the two northernmost explored ecoregions Manning-Hawkesbury and Tweed-Moreton. Pentametrocrinus and Bathycrinus are restricted to TweedMoreton and Monachocrinus occurred from Bassian to Manning-Hawkesbury.

The crinoids from the eastern coast of Australia display bathymetric and geographic contrasted distributions. More detailed taxonomic resolution is needed to help understand the biogeographic implication of these preliminary results.

\section{Asteroidea}

\section{Mah}

Surveys of Bathyal and Abyssal regions in Eastern Australia yielded a total of over 52 species of sea stars (Asteroidea) including at least six undescribed species. Nearly all of the identified species were new occurrences for the Australian region.

At least one specimen of an undescribed species of Evoplosoma was collected. Based on in situ observations by Mah (Mah 2015a, b) Evoplosoma has been regularly observed feeding on deep-sea octocorals, particularly those which form large deep-sea "forests" such as the "bamboo" corals (family Isididae), suggesting that these coral habitats occur off the Australian coast.

Among the rarest of the sea stars collected were new occurrences of the velatidans Pythonaster and two individuals of Myxaster, both in the family Myxasteridae. Both of these genera occur at great depth $(>2000 \mathrm{~m}$ and $>1000 \mathrm{~m}$ respectively) and are among the most seldom encountered of deep-sea asteroids (Mah et al. 2012). Fewer than 2 dozen specimens of either genus are known from museum collections. These are the first occurrence records of these mysterious animals from Australian waters.

Multiple occurrences of different "slime stars" in the genus Hymenaster and the related genus Calyptraster were collected. New discoveries showing gut contents of these taxa from the Great Australian Bight suggest deposit feeding or predation on molluscs present in both genera. Hymenaster contains numerous species, some of which occur widely throughout the world but it is likely that several new species occur in Australian waters but taxonomic difficulties must be addressed before this work can progress.

At least three deep-water freyellid sea stars were collected, including Astrocles, Freyella and Freyastera. Freyellids are members of the Brisingida, unusual asteroids which extend their multiple, elongate arms into the water column and capture food as it is caught by pedicellariae present on needle-like arm spines. Of the three genera collected, Astrocles represents a likely new species, and the first occurrence of this genus from the Southern Hemisphere.

Of the total number of species recorded, several of them are members of families which occur or have been observed on soft sediment, including the Astropectinidae, the Porcellanasteridae, and to a lesser extent the Zoroasteridae and the Benthopectinidae. These groups are widely different from one another, but have adaptations which permit them to exploit soft-bottom settings in different ways. Porcellanasterids for example, occur on abyssal plains and exploit finer mud than astropectinids which occupy a broad range of habitats and different sedimentary settings.

\section{Ophiuroidea}

\section{T.D. O'Hara}

The ophiuroid fauna consisted of 78 species, 296 speciessample lots, and 9192 specimens. The abyssal fauna (> $3500 \mathrm{~m}$ ) is very similar to that described for the North Atlantic Ocean (Paterson 1985) including the species: Ophiosphalma armigerum, Perlophiura profundissima, Amphiophiura bullata, Ophiura irrorata, Ophiacantha cosmica, Ophiotypa simplex and Amphiura daleus/verrilli. Most of these species have been recorded across the Atlantic, Pacific and Indian oceans, although this needs to be confirmed by genetic data. One exception is Ophiosphalma armigerum which is occurs throughout the Atlantic and across the Indian Ocean to southern Australia (as far as Hunter MP), but is replaced in the tropical west Pacific by $O$. fimbriatum and O. glabrum.

There was a clear temperate-tropical transition at mid bathyal depths. Temperate species included Astrodia tenuispina, Ophiura spinicantha, Ophiocten australis, Ophiuroglypha verrucosa, Ophioplinthus accommodata, 
Ophiocamax applicatus, Ophiacantha sollicita, Ophiernus vallincola, Amphilepis neozelandica, and Ophaictis amator. Many of these animals have been found previously in the Great Australian Bight and off New Zealand. Ophiocten australis occurred in huge numbers at some operations (e.g. $n=1685$ in beam trawl 022 and $n=519$ in sample 056). The northern group included Amphiophiura sculptilis, A. ornata, A. paraconcava, Ophiomusium granosum, Ophiosphalma fimbriatum and $O$. coricosum. These are all typical animals found by French surveys around New Caledonia. Amphiophiura paraconcava was often abundant ( $n=396$ from sample 115 and $n=1308$ from 128 ).

The widespread carnivore Ophiura flagellata was numerous $(n=49)$ in the sample $(080)$ with rotting mantra shark, but also in sample $104(n=62)$ which did not contain an obvious carcass. A few specimens represented interesting extensions of geographic range. Amphiophiura inops (sample 070) is otherwise known only from the Antarctic. Ophiotoma paucispina was previous known only from a few specimens collected by the Albatross in the tropical eastern Pacific (1891-1904). One specimen collected from the abyss off Newcastle (sample 067) has been confirmed by multi-locus DNA data to be a new genus within the Ophiotomidae.

\section{Echinoidea}

\section{A. Miskelly}

Eleven species of echinoid were identified, with most being new records for Australia. Of particular interest is the first record for an aeropsid spatangoid in Australian waters, Aeropsis sp., collected from 2600 to 2746 m. It is perhaps the most elongate and laterally compressed of all spatangoids (heart urchins), and is different to all other spatangoids in the position of the periproct (anal area) on the aboral (upper) surface. As is the case with deep water irregular echinoids, this species does not resemble their shallow water relatives. Brissopsis oldhami, known previously from New Zealand, also is a new record. Records from off Bass Strait indicate similar depths to Aeropsis. It has the more typical spatangoid form.

The schizasterid Aceste ovata is a widespread, highly specialised non-petaloid spatangoid that was collected from around $4000 \mathrm{~m}$ depth off Bass Strait. It displays a peculiar deep anterior notch, infused with dense funnelbuilding tube feet that construct a channel for moving seawater over the aboral surface for respiration. Previously it was only known from Australia by one record off Portland, Victoria at $1087 \mathrm{~m}$.

One species each of Aspidodiadema and Caenopedina were recorded, but, due to their small size and condition, were not able to be identified to species level. Both genera are widespread throughout the Indo-Pacific, so their presence was not unexpected. The saleniid,
Salenocidaris hastigera, recorded from off Byron Bay NSW, Newcastle NSW, and Fraser Island, Qld at depths ranging from $1000 \mathrm{~m}$ to $2900 \mathrm{~m}$, while not new for Australia, was previously known only from off Norfolk Island. It is widespread throughout the Indo-Pacific region.

Notocidaris bakeri, the only cidarid species recorded, was previously collected around New Zealand.

Echinothuriids were represented each by one species of Tromikosoma, Hygrosoma, and Sperosoma.

Typically, these fragile echinoids tend to fracture easily when sampled from deep water, losing spines and pedicellariae. It is possible that they are known also from off New Zealand. The temnopleurid Prionechinus sagittiger was an exciting discovery. This species was collection by the Challenger expedition from off Papua New Guinea at depths of $1990 \mathrm{~m}$ (Agassiz 1881) but little is known about its biology.

\section{Holothuroidea \\ P.M. O'Loughlin, M. Mackenzie \& T.D. O'Hara}

The bathyal and abyssal fauna found off eastern Australia was similar at the genus-level to that found in many similar habitats elsewhere in the Pacific and Atlantic Oceans (Billet 1991). In this study, the peak of diversity was at mid to lower bathyal depths (1500-3000 m) again similar to that found elsewhere (Billet 1991). More than 41 taxa were identified to species-level, including more than 12 potentially new species in the genera Psolus, Peniagone, Ellipinion, Molpadiodemas (numerous), Benthodytes ( $\times 2$ ), Paroriza, Gephyrothuria, Molpadia ( $\times$ 4), Protankyra, Prototrochus and Myriotrochus. However, several other identifications were tentative. Cryptic species-complexes with wide distributions are known to be common amongst echinoderms and future revisions based both on molecular and morphological data may well distinguish Australian species from those living in other oceans. Conversely, deep-sea holothurian phylogeographies published to date have found complexes of species with overlapping geographic and bathymetric distributions (Ross 2012; Gubili et al. 2017).

The mid to lower bathyal fauna includes taxa from all seven recognised holothuroid orders (Miller et al. 2017), although in terms of abundance, the orders the Elasipoda (particularly Amperima furcata and Benthodytes sp. nov 1) and Persiculida (Pseudostichopus peripatus and Molpadiodemas spp) dominated. The abyssal fauna $(>3500 \mathrm{~m}$ ) was generally a subset of the lower bathyal fauna, with the addition of the unusual U-shaped infaunal species Ypsilothuria bitentaculata. The upper bathyal $(<1500 \mathrm{~m})$ fauna was also a subset of the lower bathyal fauna with the addition of Orphnurgus insignis and an undetermined Benthodytes. 
Several species found in the survey are widespread and their biology has been studied in more detail elsewhere. Enypniastes eximia (sometimes known irreverently as the 'headless chicken'), a pelagic elasipod that only descends to the seabed to feed (Miller and Pawson 1990), was opportunistically collected in beam trawl 080 at $1225 \mathrm{~m}$ in the Central Eastern MP. Some of the holothurians in the family Elpidiidae are also likely to be able to swim, at least for short periods (Rogacheva et al. 2013). Scotoplanes globosa (the sea pig), collected at $2785 \mathrm{~m}$ in the Freycinet MP, forms vast herds on oceanic abyssal plains and has been called the most common megafaunal animal on the planet (Rowe et al. 2017). Psychropotes longicauda, a large purple species with a prominent sail-like dorsal appendage of unknown function, is known to be a cryptic species complex (Gubili et al. 2017). It has one of the largest eggs of any echinoderm (up to $4.4 \mathrm{~mm}$ in diameter) and appears as if it can metamorphose directly into juveniles in the plankton, having been found thousands of meters above the seafloor (Billet and Huggett 1987). The majority of the epifaunal and bathypelagic species are likely to be deposit feeders. Oneirophanta mutabilis, another species complex (Ross 2012), has been reported to continuously feed and excrete like a "conveyor belt" (Moore and Roberts 1994). It has been estimated to bioturbate up to one third of the seafloor where it is common (Witbaard et al. 2001). In many locations only females have been found, suggesting it is parthenogenetic or that males become fertile only under certain conditions (Ramirez-Llodra et al. 2005). Numerous animals that live buried in the sediment (infauna) were also collected, from the tiny Protankyra and Echinocucumis to the large Molpadia. The 'skin-digging' tanaid Exspina typica was found in the coelomic cavity of two Pseudostichpus peripatus specimens collected from Freycinet CMR at 2820 to $2751 \mathrm{~m}$. This is the first record of E. typica parasitising this particular species of holothuroid, however it has previously been observed in the intestine and body cavity of other holothuroid hosts, and an association between this parasitism and deep-water environments was confirmed by Alvaro et al. (2011).

\section{Tunicata}

\section{Ekins}

From the 100 tunicates collected during the IN2017_ V03 expedition, there were only six different species from four different families and five genera. All species collected from this voyage have previously been collected in abyssal trawls from Antarctica, Australia, the Indian and Pacific Oceans. There is only one potential new species from this expedition, Protocholozoa cf. anthos but, unfortunately it was damaged during collection and the description of a new species will have to wait until another specimen is recovered. Asjirus indicus was the most commonly collected ascidian, collected from Victoria up to the Coral Sea, from 1000 to $4000 \mathrm{~m}$ in depth. This is a species with a worldwide deep water distribution. Culeolus anonymus was the second most commonly collected ascidian, also collected from Victoria to off Fraser Island, Queensland. This species has been recorded from subantarctic to Antarctic waters in the Pacific and Atlantic Oceans previously. The other species recorded on this voyage include Culeolus recumbens, Pharyngodictyon mirable and Dicarpa lata. There were also recorded on this voyage salps Metcalfina hexagona and Thetys vagina as well as the ubiquitous Pyrosoma atlanticum.

Monniot and Monniot (2003) have previously conducted extensive abyssal tunicate work in the Pacific concentrating mainly around New Caledonia and Kott $(1969,1971)$ has studied the deep water Antarctica ascidians. The abyssal fauna collected on this expedition is very similar to abyssal fauna from the Antarctic and deep tropical waters, showing an obvious connection via the deep cold waters. The Tasman Sea and Australia, including the Coral Sea and Great Australian Bight, were surveyed by RV Dmitry Mendeleev during 1975-1976. The ascidians collected during that expedition were described in Sanamyan and Sanamyan (1999).

\section{Pisces}

\section{F. Gomon, J. J. Pogonoski, D. J. Bray, A. Graham}

The RV Investigator IN2017_V03 Abyssal Survey was Australia's first attempt to systematically sample the abyssal benthic communities of a segment of the eastern Australian coastline bordering the continent. Although occasional collections had been previously made at similar depths in Australian waters, those efforts were for the most part one-off serendipitous shots at random localities undertaken during projects with quite different goals (Tanner et al. 2018; Williams et al. 2018b). Some in fact were part of worldwide sampling efforts, like collections of the Challenger expedition undertaken in the mid-1800s, which meant vast distances between trawls to cover such a wide geographic area (Günther 1887).

Consequently, little is known about the diversity and distribution of abyssal species in Australian waters and how it compares with this interconnected environment around the world. The initial perception of fish species taken in the recent dedicated survey supported the wide held view that abyssal diversity is low and those present are widely distributed in the world oceans. Although a majority of the species encountered during this abyssal project had been previously collected, a significant number represent new records for Australia's Exclusive Economic Zone. 
Although the survey targeted depths of 2500 and 4000 $\mathrm{m}$, the nature of the bottom topography encountered necessitated sampling shallower or deeper on some transects, which meant the overall catch composition included deep slope as well as abyssal and pelagic species, the latter taken in the course of shooting and retrieving non-opening and closing sampling gear. Of the more than 100 fish species collected, a little over twothirds were bottom associated demersal species, with the remaining third pelagic forms, represented by both adults and/or early life stages, the latter in some cases of inshore species. About half of the bottom living species taken were abyssal with the other half confined to the lower parts of the continental slope. The catch included one carcass, the remains of a greatly deteriorated manta ray Mobula birostris with a pelvis almost a metre across.

At least seven of the 33 or more abyssal species (21\%) collected are confirmed first records for Australia's EEZ with a similar number still awaiting definitive identifications. The new records include Typhlonus nasus, Chaunacops coloratus, Acanthonus armatus, Lycenchelys antarctica and the three cuskeels - Paraphyonus bolini, P. rassi and Sciadonus pedicellaris noted in Nielsen et al. (2019). Virtually all of these species have extensive geographical distributions, and despite their obvious limited mobility, some, like the colourless, live-bearing, virtually, if not completely blind gelatinous cusk-eels, likely remain close to "home" their entire lives. An ophidiiform group comprising the live-bearing family Bythitidae and the egg laying Ophidiidae, is one of two dominant evolutionary lines in the deepest parts of our oceans worldwide. The latter includes Typhlonus nasus, dubbed the "Faceless Fish" by a member of the fish team for its lack of discernible eyes, eye-like nostrils and underslung mouth, which initially masked its family relationships. In the end, it and the four other examples collected were found to be a species that was originally described from the Coral Sea just outside Australia's EEZ 140 years ago, but is only now verified as occurring in Australian waters. Examples of this ophidiiform group also included the massive Spectrunculus grandis, initially described from Japanese waters a year before the previous species, and reaching well over a metre in length. Both are widely distributed in Indian and Pacific oceans. Although the two examples reach quite a large size, many species occurring at these depths tend to be rather small, rarely exceeding $10-20 \mathrm{~cm}$ in length. The aphyonidclade of cusk eels collected by the expedition was reviewed by Nielsen et al. (2019) who recognised five distinct species around Australia.

Another particularly diverse group at abyssal depths is the order Aulopiformes, ranging from the ferocious looking deepsea lizardfishes Bathysaurus ferox (family Bathysauridae), their extensive gape so full of needle-like teeth that they spill out onto the sides of the jaws, to the stilt-perched tripodfishes (family Ipnopidae) that await patiently on their prolonged fin rays for meals to come to them. The latter family was represented in the survey by eight long-finned species and three bottom huggers, including the odd looking Spiderfish of the genus Ipnops with large yellowish luminous oval plates where eyes should be and a second Australian specimen of the Shortarse Feelerfish Bathymicrops brevianalis. The species identity of the Ipnops remains in question, as the DNA of several specimens analysed (Coral Sea) differs from that of specimens collected in the Great Australian Bight. The tripodfishes represented comprised a significant proportion of the total number of species known to occur in the Indian and Pacific Oceans (Sulak 1977).

From a biomass perspective, members of the Basketwork Eel family Synaphobranchidae were important with seven species taken during the survey and the Southern Cut-throat Eel, Histiobranchus australis, which attains a length of about $70 \mathrm{~cm}$, present at almost all of the 2500 $\mathrm{m}$ collection sites from Tasmania to the Coral Sea, demonstrating its dominance in this environment. Prior to recent deep-water sampling made possible by the RV Investigator's increased capability, this species was known in Australia from one or two specimens collected during international exploration. So, an apparently rare species is now seemingly common with over 30 specimens known from Australia. Basketwork eels are among the most numerous and often collected of the deep benthic fishes worldwide where they feed indiscriminately on available prey.

The brilliant red-orange Red Coffinfish Chaunacops coloratus, previously known only from the northern $\mathrm{Pa}$ cific and eastern Indian Oceans, is one of the deepest dwelling members of a particularly deep, bottom living family of anglerfishes. Underwater videos taken in the Pacific show this species to puff up by inhaling water in an attempt to intimidate predators before "beating feet" when the ploy doesn't work. Other members of this family are generally confined to the continental slopes of the world.

Some shallow dwelling families of the temperate Northern Pacific, like the scorpionfish relatives the Snailfishes (family Liparidae) and the Eelpouts (family Zoarcidae) are absent in the shallows of the Southern Hemisphere, but do have examples in the southern deep-sea. For the most part these species dwell on the slopes of seamounts above the abyssal plain, but a specimen of the eelpout genus Lycenchelys antarctica was represented by a single specimen that is the first record for continental Australia. This is, as the name implies, an Antarctic species, which may have been a vagrant carried northwards by north flowing Antarctic Bottom Water that supplies abyssal waters of the world. 
The expedition provided a significant glimpse of Australian ichthyo-diversity at these depths. The results show a similarity with that of other parts of the lower bathyal and abyss in world oceans.

\section{Discussion}

The IN2017_V03 expedition of Australia's premier research vessel Investigator was the first to systematically sample lower bathyal to abyssal habitats (2000-5000 m) in Australia's Exclusive Economic Zone. It traversed seven newly declared marine parks in Commonwealth waters off the eastern margin of Australia from 15th May to 16th June 2017, including Freycinet, Flinders, East Gippsland, Jervis, Hunter, Central Eastern and Coral Sea Marine Parks. The voyage mapped much of the deeper water habitats of these parks using high resolution multi-beam data and systematically sampled the benthic habitats, principally using video transects, small beam trawls and epibenthic sleds. Importantly, the survey traversed both areas of high primary productivity at temperate latitudes near Tasmania and more oligotrophic areas of the northern Tasman Sea.

The current paper does not include all the smaller crustaceans (e.g. ostracods, amphipods, tanaids) or groups like nematodes that were collected by the Brenke sled. These await further taxonomic examination. Indeed, the collections represent a valuable morphological and genetic resource for the continuing study of the Australian marine fauna. The survey also targeted softsediment habitats avoiding areas of exposed rock. Exposed rocky substrata were common at the base of the continental margin, where strong bottom currents clear sediment and produce "moats" at the edge of the abyssal plain. Other areas of rock occurred at bathyal depths on the sides of canyons and edges of escarpments (Keene et al. 2008). The fauna of these rocky areas is generally different from that on soft-sediment substrata, even at abyssal depths (e.g. Simon-Lledó et al. 2019).

Given the lack of previous knowledge, it is not surprising that over half of the fauna is new to science. The fact that $42 \%$ of the taxa could be assigned a species name is evidence of the widespread ranges of many bathyal and abyssal species. Many species, genera and even families have now been reported from Australian waters for the first time.

The relationships of the fauna are dependent on latitude. The species off SE Australia are shared with the southern Indian Ocean, the Southern Ocean or New Zealand. Some species extend as far as the North Atlantic Ocean. The fauna off NE Australia is typically distributed at similar depths across the tropical Indo-Pacific Oceans (approximately less than $30^{\circ}$ latitude in both hemispheres). Emerging DNA evidence supports these patterns. For example, DNA evidence shows that the abyssal ophiuroid Ophiosphalma armigerum occurs from the North Atlantic Ocean, around South Africa to the southern Tasman Sea. Whereas this species is replaced in tropical latitudes across the Indo-Pacific by the species $O$. fimbriatum and O. glabrum, the latter extending to the Clarion Clipperton Zone in the NE Pacific (Christodoulou et al. 2019). It is unclear what biogeographic processes could give rise to a temperate-tropical biogeographical transition at abyssal depths (O'Hara et al. 2020b).

Determining levels of endemism will have to await taxonomic revisions or phylogeographic studies of many deep-sea animal groups. Available evidence is too fragmentary for most species to establish distributional ranges with any certainty. Under-sampling is known to cause over-estimation of apparent endemism (Coddington et al. 2009). Nevertheless, some groups appear to exhibit elevated levels of regional differentiation around Australia. For example, only two sponge species were found to be shared between the lower bathyal and abyssal fauna off eastern Australia and that found in the Great Australian Bight off southern Australia.

It is difficult to compare the diversity of deep-sea communities across regions due to the great variability in collection gear and taxonomic coverage (Gray 2002). Fortunately, lower-bathyal and abyssal collections from the Great Australian Bight (GAB, $1700 \mathrm{~km}$ to the west of the IN2017_V03 sampling transect) have been collected using the same gear (beam trawl from the RV Investigator) and were identified by many of the same taxonomists that are co-authors of this paper (MacIntosh et al. 2018; Williams et al. 2018a). Using multivariate statistics, rarefaction and model-based ranked abundance distributions (RAD), we compared animal abundance and species richness between samples from the GAB to those from the south and north sectors of our voyage (O'Hara et al. 2020a). Samples with the highest standardised abundance and species richness were found at depths of 2500-3000 m off SE Australia. These samples are situated under a seasonal plankton bloom, and carbon flux to the seafloor was identified as the most important measured environmental variable driving the RAD models (O'Hara et al. 2020a). From this peak, abundance and richness decreased both with depth and distance, in both north and westerly directions (GAB region). These finding are congruent with the findings of a global study on ophiuroids by Woolley et al. (2016), who found that peaks of species richness at lower bathyal and abyssal depths occurred in temperate zones associated with peaks in surface productivity. This pattern differs from that in shallow water, which exhibits the well-known latitudinal decrease in richness from tropical to polar regions (Tittensor et al. 2010; Woolley et al. 2016). 
The lower bathyal and abyssal (2000-5000 m) fauna of Australia is now known from the GAB and from off the eastern coast (O'Hara et al. 2020a). But many gaps remain in our knowledge of the seafloor fauna from Australia's Exclusive Economic Zone, the third largest of any nation. In particular, we have little to no information about the deep-sea fauna of the west coast, from off SW Western Australia to the Timor Trench. Other gaps include off Western Bass Strait, southern Tasmania, the Coral Sea Basin, and around most of Australia's offshore islands.

\section{Conclusions}

The lower bathyal and abyssal fauna of soft sediment seafloors off eastern Australia has been systematically surveyed for the first time. The result is a rich collection of invertebrates and fish that considerably improves the knowledge of the composition and distribution of southern hemisphere faunas from this depth range. Approximately $58 \%$ of the identified taxa could not be assigned to a described species. Many described species are recorded from the Tasman Sea for the first time. The resultant collections will provide the foundation for much future ecological, biogeographical, phylogenetic and taxonomic research.

\section{Supplementary information}

Supplementary information accompanies this paper at https://doi.org/10 1186/s41200-020-00194-1.

Additional file 1: Supplementary Table S1. Provisional list of taxa

identified from the voyage IN2017_V03.

\begin{abstract}
Acknowledgements
The authors wish to thank the CSIRO Marine National Facility (MNF) for its support in the form of sea time on RV Investigator, support personnel, scientific equipment and data management. All data and samples acquired on the voyage are made publicly available in accordance with MNF Policy. We also thank all the scientific staff and crew who participated in voyage IN2017_V03; participating taxonomists who chose not to join the list of authors, Lisa Goudie (sponges), Ella Lejune (sponges, Queensland Museum) and Candice Untiedt (octocorals, University of Tasmania); and voyage participants, Jérôme Mallefet (Université Catholique de Louvain) and Robert Zugaro (MV), who contributed photos.
\end{abstract}

\section{Authors' contributions}

$\mathrm{TOH}, \mathrm{AW} \& \mathrm{NB}$ designed the study and $\mathrm{TOH} \& \mathrm{AW}$ led the voyage. DB, MEk, MEl, CAF, MNG, AG, MG, KGH, FK, EK, MM, KM, JP, DS participated in the voyage. TOH co-ordinated the manuscript. TOH, STA, PA, TA, DB, IB, NB, FC, ALC, MEK, MEl, CAF, JKF, MNG, AG, MG, KGH, LMG, AH, AMH, PH, HK, FK, JK, EK, CCL, MM, CH, HM, KLM, AM, MLM, KM, AH, PMO, HP, JP, SD, JEW, RSW, JZ provided taxonomic identifications and biodiversity descriptions. The author(s) read and approved the final manuscript.

\section{Funding}

Project funding was provided by the Marine Biodiversity Hub, supported through the Australian Government's National Environmental Science Program (NESP). Funding bodies were not involved in the design of the study, the collection, analysis, and interpretation of data, or in the writing of the manuscript.

\section{Availability of data and materials}

The datasets used and/or analysed during the current study are available from the corresponding author on reasonable request. Specimens are lodged at participating Australian museums (Museums Victoria, Australian Museum, Queensland Museum and Tasmanian Museum and Art Gallery) and are available for study.

\section{Ethics approval and consent to participate}

The material was lawfully collected under the following permits: (1) Access to Biological Resources in a Commonwealth Area for Non-Commercial Purposes, AU-COM2017-352; (2) Approval for Activity in a Commonwealth Marine Reserve, CMR-17-000455; (3) Australian Fisheries Management Authority Scientific Permit, $100339+3$; (4) Queensland Government General Fisheries Permit, 191670; (5) Museums Victoria Animal Ethics Committee approval, MV AEC 17001.

\section{Consent for publication}

Not applicable.

\section{Competing interests}

The authors declare that they have no competing interests.

\section{Author details}

${ }^{1}$ Museums Victoria, Melbourne, Australia. ${ }^{2}$ CSIRO Oceans and Atmosphere, Hobart, Australia. ${ }^{3}$ Australian Museum Research Institute, Sydney, Australia. ${ }^{4}$ Natural History Collections, University of Bergen, Bergen, Norway. ${ }^{5}$ South Australian Museum, Adelaide, Australia. ${ }^{6}$ Queensland Museum, Brisbane, Australia. ${ }^{7}$ Muséum national d'Histoire Naturelle, Paris, France. ${ }^{8}$ Life Sciences Department, Natural History Museum, London, UK. ${ }^{9}$ Australian National Fish Collection, CSIRO, Hobart, Australia. ${ }^{10}$ Western Australian Museum, Perth, Australia. ${ }^{11}$ Department of Biological Sciences, Macquarie University, Macquarie Park, Australia. ${ }^{12}$ Molecular Invertebrate Systematics and Ecology Laboratory, University of the Ryukyus, Nishihara, Japan. ${ }^{13}$ National Museum of Natural History (Smithsonian), Washington DC, USA. ${ }^{14}$ Tasmanian Museum and Art Gallery, Hobart, Australia. ${ }^{15}$ South China Sea Environmental Monitoring Centre, Guangzhou, P. R. China. ${ }^{16}$ Institute for Marine and Antarctic Science, Hobart, Australia.

Received: 5 January 2020 Accepted: 24 August 2020

Published online: 18 September 2020

\section{References}

Agassiz A. Echinoidea. Report on the scientific results of the voyage of the HMS Challenger. Zoology. 1881;3:1-321 pls 1-45.

Ahyong ST. Deepwater crabs from seamounts and chemosynthetic habitats off eastern New Zealand (Crustacea: Decapoda: Brachyura). Zootaxa. 2008;1708: $1-72$.

Ahyong ST. New species and new records of Caridea (Hippolytidae, Pasiphaeidae) from New Zealand. Zootaxa. 2010;2372:341-57.

Ahyong ST. Cymonomid crabs from New Zealand and Australia (Crustacea: Decapoda: Cyclodorippoida). Rec Aust Mus. 2019;71:33-69.

Ahyong ST, Farrelly CA. First Australian records of Ethusina (Crustacea: Decapoda: Ethusidae) and additional records from New Zealand. Zootaxa. 2018;4486: $161-8$.

Allen JA. The adaptations and radiation of deep sea bivalves. Sarsia. 1979;64: 19-27.

Allen JA. Bivalvia of the deep Atlantic. Malacologia. 2008;50:57-173.

Allen JA, Sanders HL. Adaptations to abyssal life as shown by the bivalve Abra profundorum (Smith). Deep Sea Res. 1966;13:1175-84.

Allman GJ. Report on the Hydroida dredged by H.M.S. Challenger during the years 1873-76. Part II. The Tubularinae, Corymorphinae, Campanularinae, Sertularinae and Thalamophora. Report on the scientific results of the voyage of HMS Challenger during the years 1873-76. Zoology. 1888;23:1-90 pls 1-20.

Alvaro MC, Blażewicz-Paszkowycz M, Davey N, Schiaparelli S. Skin-digging tanaids: the unusual parasitic behaviour of Exspina typica in Antarctic waters and worldwide deep basins. Antarct Sci. 2011;23:343-8.

Baba K, Macpherson E, Poore GCB, Ahyong ST, Bermudez A, Cabezas P, et al. Catalogue of squat lobsters of the world (Crustacea: Decapoda: Anomura_families Chirostylidae, Galatheidae and Kiwaidae). Zootaxa. 2008; 1905:1-220. 
Bale WM. Report on the Hydroida collected in the Great Australian Bight and other localities. Biological results of the fishing experiments carried on by FIS "Endeavour" 1909-1914. 1914a;2:3-62 pls 1-7.

Bale WM. Report on the Hydroida collected in the Great Australian Bight and other localities. Biological results of the fishing experiments carried on by FIS "Endeavour" 1909-1914. 1914b;2:164-88 pls 35-38.

Bale WM. Report on the Hydroida collected in the Great Australian Bight and other localities. Biological results of the fishing experiments carried on by FIS "Endeavour" 1909-1914. 1915;3:241-336 pls 46-47.

Billet DSM. Deep-sea holothurians. Oceanogr Mar Biol Annu Rev. 1991;29:259-317.

Billet DSM, Huggett QJ. Echinodermata. In: Roe HSJ, editor. Great Meteor East: a biological characterisation, Rep Inst Oceanogr Sci Deacon Lab; 1987; 248: 109-18.

Bouchet $P$, Héros V, Lozouet P, Maestrati P. A quarter-century of deep-sea malacological exploration in the south and west Pacific: where do we stand? how far to go? In: Héros V, Cowie RH, Bochet $P$, editors. Tropical Deep-Sea Benthos 25, Mém Mus Natl Hist Nat, vol. 196; 2008. p. 9-40.

Braid HE, Bolstad KSR. Systematics of the Mastigoteuthidae Verrill, 1881 (Cephalopoda: Oegopsida) from New Zealand waters. NZ J Zool. 2015;42: $187-256$.

Brandt A, Brix S, Brökeland W, Choudhury M, Kaiser S, Malyutina M. Deep-sea isopod biodiversity, abundance, and endemism in the Atlantic sector of the Southern Ocean-results from the ANDEEP I-III expeditions. Deep Sea Res II. 2007;54:1760-75

Brandt A, Linse K, Schüller M. Bathymetric distribution patterns of Southern Ocean macrofaunal taxa: Bivalvia, Gastropoda, Isopoda and Polychaeta. Deep Sea Res I. 2009;56:2013-25.

Brenke N. An epibenthic sledge for operations on marine soft bottom and bedrock. Mar Technol Soc J. 2005;39:10-9.

Bruun AF. General introduction to the reports and list of deep-sea stations. Galathea Rep. 1957;1:7-48

Burnett WJ, Benzie JAH, Beardmore JA, Ryland JS. Patterns of genetic subdivision in populations of a clonal cnidarian, Zoanthus coppingeri, from the Great Barrier Reef. Mar Biol. 1995;122:665-73.

Burnett WJ, Benzie JAH, Beardmore JA, Ryland JS. Zoanthids (Anthozoa, Hexacorallia) from the Great Barrier Reef and Torres Strait, Australia: systematics, evolution and a key to species. Coral Reefs. 1997;16:55-68.

Calder DR, Vervoort W. Some hydroids (Cnidaria: Hydrozoa) from the Mid-Atlantic Ridge, in the North Atlantic Ocean. Zool Verh. 1998;319:1-65.

Capa M, Parapar J, Hutchings P. Phylogeny of Oweniidae (Polychaeta) based on morphological data and taxonomic revision of Australian fauna. Zool J Linnean Soc. 2012;166:236-78.

Carreiro-Silva M, Ocaña O, Stanković D, Sampaio I, Porteiro FM, Fabri M-C, et al. Zoantharians (Hexacorallia: Zoantharia) associated with cold-water corals in the Azores region: new species and associations in the deep sea. Front Mar Sci. 2017:4:88.

Christodoulou M, O'Hara TD, Hugall AF, Arbizu PM. Dark ophiuroid biodiversity in a prospective abyssal mine field. Curr Biol. 2019;29:3909-12.e3.

Coddington JA, Agnarsson I, Miller JA, Kuntner M, Hormiga G. Undersampling bias: the null hypothesis for singleton species in tropical arthropod surveys. J Anim Ecol. 2009;78:573-84.

Condie S. A circulation model of the abyssal Tasman Sea. Deep Sea Res I. 1994; 41:9-22.

Crowther AL, Fautin DG, Wallace CC. Stylobates birtlesi sp. n., a new species of carcinoecium-forming sea anemone (Cnidaria, Actiniaria, Actiniidae) from eastern Australia. Zookeys. 2011;89:33-48.

Danovaro R, Snelgrove PVR, Tyler P. Challenging the paradigms of deep-sea ecology. Trends Ecol Evol. 2014;29:465-75.

Dijkstra HH. Bathyal Pectinoidea (Bivalvia: Propeamussiidae, Entoliidae, Pectinidae) from New Caledonia and adjacent areas. In: Bouchet P, editor. 'Resultats des campagnes Musorstom', volume 14, Mémoires du Muséum National d'Histoire Naturelle, vol. 167; 1994. p. 9-73.

Distel DL, Amin M, Burgoyne A, Linton E, Mamangkey G, Morrill W, et al. Molecular phylogeny of Pholadoidea Lamarck, 1809 supports a single origin for xylotrophy (wood feeding) and xylotrophic bacterial endosymbiosis in Bivalvia. Mol Phylogenet Evol. 2011;61:245-54

Dolan E. Systematics, phylogenetics and biogeography of deep sea Pennatulacea (Anthozoa: Octocorallia) evidence from molecules and morphology. PhD Dissertation: Faculty of Engineering, Science and Mathematics: School of Ocean and Earth Sciences: University of Southhampton, UK; 2008. (URL https://eprints.soton.ac.uk/65669/1/Dolan_2008_PhD.pdf).
Drennan R, Wiklund H, Rouse GW, Georgieva MN, Wu X, Kobayashi G, et al. Taxonomy and phylogeny of mud owls (Annelida: Sternaspidae), including a new synonymy and new records from the Southern Ocean, north East Atlantic Ocean and Pacific Ocean: challenges in morphological delimitation. Mar Biodivers. 2019;49:2659-97.

Ekins M, Erpenbeck D, Hooper JNA. Carnivorous sponges from the Australian bathyal and abyssal zones collected during the RV Investigator 2017 expedition. Zootaxa. 2020;4774:1-159.

Elsner NO, Malyutina MV, Golovan OA, Brenke N, Riehl T, Brandt A. Deep down: isopod biodiversity of the Kuril-Kamchatka abyssal area including a comparison with data of previous expeditions of the RV Vityaz. Deep Sea Res II. 2015;111:210-9.

Falkowski PG, Algeo T, Codispoti L, Deutsch C, Emerson S, Hales B, et al. Ocean deoxygenation: past, present, and future. Eos. 2011;92:409-10.

Farrelly CA, Ahyong ST. Deepwater decapod, stomatopod and lophogastrid Crustacea from eastern Australia and the Great Australian Bight in 2015-2017: preliminary identifications of 191 species. Mus Vict Sci Rep. 2019;21:1-97.

Fautin DG, Malarky L, Soberon J. Latitudinal diversity of sea anemones (Cnidaria: Actiniaria). Biol Bull. 2013;224:89-98.

Fujii T, Reimer JD. Phylogeny of the highly divergent family Microzoanthidae (Anthozoa, Hexacorallia) from the Pacific. Zool Scr. 2011;40:418-31.

Fujii T, Reimer JD. A new family of diminutive zooxanthellate zoanthids (Hexacorallia: Zoantharia). Zool J Linnean Soc. 2013;169:509-22.

Gaina C, Müller DR, Royer J-Y, Stock J, Hardebeck J, Symonds P. The tectonic history of the Tasman Sea: a puzzle with 13 pieces. J Geophys Res Biogeosci. 1998;103:12413-33.

Glasby GP, Stoffers P, Grapes RH, Pluger WL, McKnight DG, Main W. Manganese nodule occurrence in the Tasman Sea. NZ J Mar Freshw Res. 1986;20:489-94.

Gleadall IG, Guerrero-Kommritz J, Hochberg FG, Laptikhovsky W. The inkless octopuses (Cephalopoda: Octopodidae) of the Southwest Atlantic. Zool Sci. 2010;27:528-53.

Golovan OA, Błażewicz M, Brandt A, Jażdżewska AM, Jóźwiak P, Lavrenteva AV, et al. Diversity and distribution of peracarid crustaceans (Malacostraca) from the abyss adjacent to the Kuril-Kamchatka Trench. Mar Biodivers. 2019;49: 1343-1360.

Gray JS. Species richness of marine soft sediments. Mar Ecol Prog Ser. 2002;244: 285-97.

Gubili C, Ross E, Billett DSM, Yool A, Tsairidis C, Ruhl HA, et al. Species diversity in the cryptic abyssal holothurian Psychropotes longicauda (Echinodermata). Deep Sea Res II. 2017;137:288-96.

Günther ACLG. Report on the deep-sea fishes collected by H.M.S. Challenger during the years 1873-1876. Report on the scientific results of the voyage of the "Challenger". Zoology. 1887;22:i-Ixv + 1-268.

Gunton LM, Kupriyanova E, Alvestad T. Two new deep-water species of Ampharetidae (Annelida: Polychaeta) from the eastern Australian continental margin. Rec Aust Mus. 2020;72:101-21.

Haddon AC, Shackleton AM. Actiniae: I. Zoantheae. In Reports on the zoological collections made in the Torres Straits by Professor A.C. Haddon, 1888-1889. Sci Rep R Dublin Soc. 1891;4:673-58.

Hallan A, Criscione F, Fedosov AE, Puillandre N. Bouchetispira ponderi n. sp. (Conoidea: Bouchetispiridae), a new deep-sea gastropod from temperate Australia. Molluscan Res. 2020;40:86-92.

Huang Z, Nichol SL, Harris PT, Caley MJ. Classification of submarine canyons of the Australian continental margin. Mar Geol. 2014;357:362-83.

Hubble T, Yu P, Airey D, Clarke S, Boyd R, Keene J, et al. Physical properties and age of continental slope sediments dredged from the eastern Australian continental margin - implications for timing of slope failure. In: Yamada $Y$, Kawamura K, Ikehara K, Ogawa Y, Urgeles R, Mosher D, et al., editors. Submarine mass movements and their consequences advances in natural and technological hazards research, vol. 31. Dordrecht: Springer; 2012.

Hutchings P, McRae J. The Aphroditidae (Polychaeta) from Australia, together with a redescription of the Aphroditidae collected during the Siboga expedition. Rec Aust Mus. 1993;45:279-363.

Jones DS, Anderson JT, Anderson DT. Checklist of the Australian Cirripedia. Tech Rep Aust Mus. 1990;3:1-38.

Jumars PA, Dorgan KM, Lindsay SM. Diet of worms emended: an update of Polychaete feeding guilds. Annu Rev Mar Sci. 2015;7:497-520.

Just J, Kristensen RM, Olesen J. Dendrogramma, new genus, with two new nonBilaterian species from the marine bathyal of southeastern Australia (Animalia, Metazoa incertae sedis) - with similarities to some medusoids from the Precambrian Ediacara. PLoS One. 2014;9:e102976. 
Kamenev GM. Bivalve molluscs of the abyssal zone of the Sea of Okhotsk: species composition, taxonomic remarks, and comparison with the abyssal fauna of the Pacific Ocean. Deep Sea Res II. 2017;154:230-48.

Keene J, Baker C, Tran M, Potter A. Geomorphology and sedimentology of the east marine region of Australia. Geoscience Australia, record 2008/10. Canberra: Geoscience Australia; 2008.

Kise H, Dewa N, Reimer JD. First record of sea urchin-associated Epizoanthus planus from Japanese waters and its morphology and molecular phylogeny. Plankton Benthos. 2018;13:136-41.

Kise H, Maeda T, Reimer JD. A phylogeny and the evolution of epizoism within the family Hydrozoanthidae with description of a new genus and two new species. Mol Phylogenet Evol. 2019a;130:304-14.

Kise H, Montenegro J, Ekins M, Takeya M, Reimer JD. A molecular phylogeny of carcinoecium-forming Epizoanthus (Hexacorallia: Zoantharia) from the Western Pacific Ocean with descriptions of three new species. Syst Divers. 2019b;17:773-86.

Knudsen J. The bathyal and abyssal Xylophaga (Pholadidae, Bivalvia). Galathea Rep. 1961;5:163-209.

Knudsen J. The systematics and biology of abyssal and hadal Bivalvia. Galathea Rep. 1970;11:1-241.

Koltun VM. Sponge fauna of the northwestern Pacific from the shallows to the hadal depths. In: Bogorov VG, editor. Fauna of the Kurile-Kamchatka Trench and its environment. Moskwa: Akademiya Nauk SSSR. Trudy Instituta Okeanologii in P.P. Shishov and Izdatelstvo Nauka; 1970.

Komai T. A review of the Indo-West Pacific species of the genus Glyphocrangon A. Milne-Edwards, 1881 (excluding the G. caeca species group) (Crustacea: Decapoda: Caridea: Glyphocrangonidae). In: Marshall BA, Richer de Forges B, editors. Tropical Deep-Sea Benthos, vol. 23, Mémoires du Muséum National d'Histoire Naturelle, vol. 191; 2004. p. 375-610.

Kott P. Antarctic Ascidia. A monographic account of the known species based on specimens collected under U.S. Government auspices 1947 to 1963. Antarct Res Ser. 1969;13:1-239.

Kott P. Antarctic ascidiacea II. Collections in south of $40^{\circ}$ south latitude 1963/67 principally by the USNS Eltanin. Antarct Res Ser. 1971;16:1-60.

Lévi C. Spongiaires des zones bathyale, abyssale et hadale. Galathea Rep. 1964;7: 63-112.

Lévi C. Porifera Demospongiae: Spongiaires bathyaux de Nouvelle-Calédonie, récoltés par le 'Jean Charcot' Campagne BIOCAL, 1985. In: Crosnier A, editor. Résultats des Campagnes MUSORSTOM, Volume 11, Mémoires du Muséum National d'Histoire Naturelle, vol. 158; 1993. p. 9-87.

Lewis M. The CSIRO $4 \mathrm{~m}$ beam trawl. In: CSIRO marine and atmospheric research paper, vol. 33; 2010. p. 1-14.

López-González PJ, Williams GC. A new deep-sea pennatulacean (Anthozoa: Octocorallia: Chunellidae) from the porcupine abyssal plain (NE Atlantic). Helgol Mar Res. 2011;65:309-18.

Lorion J, Buge B, Cruaud C, Samadi S. New insights into diversity and evolution of deep-sea Mytilidae (Mollusca: Bivalvia). Mol Phylogenet Evol. 2010;57:71-83.

Lu CC. Cephalopoda. In: Wells A, Houston WWK, editors. Zoological catalogue of Australia Mollusca: Aplacophora, Polyplacophora, Scaphopoda, Cephalopoda. Melbourne. Australia: CSIRO Publishing; 2001.

Lu CC, Dunning MC. Subclass Coleoidea Bather, 1888. Fauna of Australia volume 5 Mollusca the southern synthesis. Canberra: Australian Government Publishing Service; 1998.

Lutz MJ, Caldeira K, Dunbar RB, Behrenfeld MJ. Seasonal rhythms of net primary production and particulate organic carbon flux describe biological pump efficiency in the global ocean. J Geophys Res Biogeosci. 2007;112:C10011.

Maclntosh H, Althaus F, Williams A, Tanner JE, Alderslade P, Ahyong ST, et al. Invertebrate diversity in the deep GreatAustralian Bight (200-5000 m). Mar Biodivers Rec. 2018;11:1-21.

Mah CL. A new Atlantic species of Evoplosoma with taxonomic summary and in situ observations of Atlantic deep-sea corallivorous Goniasteridae (Valvatida; Asteroidea). Mar Biodivers Rec. 2015a;8:1-8.

Mah CL. New species, corallivory, in situ video observations and overview of the Goniasteridae (Valvatida, Asteroidea) in the Hawaiian region. Zootaxa. 2015b; 3926:211-28.

Mah CL, Mercier A, Hamel J-P, Nizinski M. Distribution data and taxonomic notes on Atlantic Myxasteridae. Zootaxa. 2012;3572:55-62.

Marques AC, Peña Cantero AL, Migotto AE. Revision of the genus Cryptolarella Stechow, 1913 (Lafoeidae, Leptothecata, Hydrozoa). J Nat Hist. 2005;39:709-22.

Martinez IJ. Late Pleistocene carbonate dissolution patterns in the Tasman Sea. In: van der Lingen GJ, Swanson K, Muir RJ, editors. Evolution of the Tasman Sea Basin. Rotterdam: Balkema; 1994.
Miller AK, Kerr AM, Paulay G, Reich M, Wilson NG, Carvajal Jl, et al. Molecular phylogeny of extant Holothuroidea (Echinodermata). Mol Phylogenet Evol. 2017;111:110-31.

Miller JE, Pawson DL. Swimming Sea cucumbers (Echinodermata: Holothuroidea): a survey, with analysis of swimming behaviour in four bathyal species. Smithson Contrib Mar Sci. 1990;35:1-18.

Monniot F, Monniot C. Ascidies de la pente externe et bathyales de l'ouest Pacific. Zoosystema. 2003;25:681-749.

Montenegro J, Sinniger F, Reimer JD. Unexpected diversity and new species in the sponge-Parazoanthidae association in southern Japan. Mol Phylogenet Evol. 2015;89:73-90.

Moore HM, Roberts D. Feeding strategies in abyssal holothurians. In: David B, Guille A, Féral J-P, Roux M, editors. Echinoderms through time: proceedings of the eighth international echinoderm conference Dijon, France, 6-10 September 1993. Rotterdam: Balkema; 1994.

Morton B. Prey capture in the carnivorous septibranch Poromya granulata (Bivalvia: Anomalodesmata: Poromyacea). Sarsia. 1981;66:241-56.

Morton B. Siphon structure and prey capture as a guide to affinities in the abyssal Septibranch Anomalodesmata (Bivalvia). Sarsia. 1987;72:49-69.

Morton B, Thurston MH. The functional morphology of Propeamussium lucidum (Bivalvia: Pectinacea), a deep-sea predatory scallop. J Zool. 1989;218(3):471-96.

Murray J. A summary of the scientific results. I-II. Report on the scientific results of the voyage of HMS Challenger during the Years 1872-76. 1895; Summary Pt 2: 1-1608, pls 1-22.

Nesis KN. Mastigoteuthis psychrophila sp. n. (Cephalopoda, Mastigoteuthidae) from the Southern Ocean. [In Russian with English summary]. Zool Zhurnal. 1977:56:835-41.

Nielsen JG, Pogonoski JJ, Appleyard SA. Aphyonid-clade species of Australia (Teleostei, Bythitidae) with four species new to Australian waters and a new species of Barathronus. Zootaxa. 2019;4564:554-72.

O'Hara TD, Hugall AF, MacIntosh H, Naughton KM, Williams A, Moussalli A. Dendrogramma is a siphonophore. Curr Biol. 2016;26:R445-R60.

O'Hara TD, Williams A, Althaus F, Ross AS, Bax NJ. Regional-scale patterns of deep seafloor biodiversity for conservation assessment. Divers Distrib. 2020a; 26: 479-494.

O'Hara TD, Williams A, Woolley SNC, Nau AW, Bax NJ. Deep-sea temperatetropical faunal transition across uniform environmental gradients. Deep Sea Res I. 2020b;161:103283.

O'Shea S. The marine fauna of New Zealand: Octopoda (Mollusca: Cephalopoda). NIWA Biodivers Mem. 1999;112:1-280.

Oliver G, Allen JA. The functional and adaptive morphology of the Deep-Sea species of the Arcacea (Mollusca: Bivalvia) from the Atlantic. Philos Trans R Soc Lond B. 1980;291:45-76.

Paterson GLJ. The deep-sea Ophiuroidea of the North Atlantic Ocean. Bull Br Mus nat Hist (Zool). 1985;49:1-162

Paterson GLJ, Glover AG, Barrio Froján CRS, Whitaker A, Budaeva N, Chimonides J, et al. A census of abyssal polychaetes. Deep Sea Res II. 2009;56:1739-46.

Philipp NA, Fautin DG. Three new species of shallow water, yellow zoanthids (Hexacorallia: Zoanthidea: Epizoanthidae) from southern California, USA, and southern Australia. Zootaxa. 2009;2058:53-61.

Poutiers J-M, Bernard FR. Carnivorous bivalve molluscs (Anomalodesmata) from the tropical western Pacific Ocean, with a proposed classification and a catalogue of recent species. Campagnes MUSORSTOM vol. 14. Mém Mus Natl Hist Nat. 1995;167:107-87.

Ramirez-Llodra E, Reid WDK, Billet DSM. Long-term changes in reproductive patterns of the holothurian Oneirophanta mutabilis from the porcupine abyssal plain. Mar Biol. 2005;146:683-93.

Rathbun MJ. The Brachyura and Macrura of the Hawaiian islands. Bull US Fish Comm. 1906;23:827-930.

Reimer JD, Hirano S, Fujiwara Y, Sinniger F, Maruyama T. Morphological and molecular characterization of Abyssoanthus nankaiensis, a new family, new genus and new species of deep-sea zoanthid (Anthozoa: Hexacorallia: Zoantharia) from a northwest Pacific methane cold seep. Invertebr Syst. 2007 21:255-62.

Reimer JD, Nonaka M, Sinniger F, Iwase F. Morphological and molecular characterization of a new genus and new species of parazoanthid (Anthozoa: Hexacorallia: Zoantharia) associated with Japanese red coral. Coral Reefs. 2008:27:935-49.

Reimer JD, Ono S, Fujiwara Y, Takishita K, Tsukahara J. Reconsidering Zoanthus spp diversity: molecular evidence of conspecificity within four previously presumed species. Zool Sci. 2004;21:517-25. 
Reiswig HM, Kelly M. The marine fauna of New Zealand: Hexasterophoran glass sponges of New Zealand (Porifera: Hexactinellida: Hexasterophora): orders Hexactinosida, Aulocalycoida and Lychniscosida. NIWA Biodivers Mem. 2011; 130:1-174.

Rex MA, Etter RJ. Deep-sea biodiversity: pattern and scale: Harvard University Press, Cambridge MA; 2010

Ridgway KR, Dunn JR. Mesoscale structure of the mean east Australian current system and its relationship with topography. Prog Oceanogr. 2003;56:189-222.

Ridgway KR, Dunn JR, Wilkin JL. Ocean interpolation by four-dimensional least squares -application to the waters around Australia. J Atmos Ocean Tech. 2002;19:1357-75

Ridley SO, Dendy A. Preliminary report on the Monaxonida collected by H.M.S. Challenger. Ann Mag Nat Hist. 1886;18:325-51 470-93.

Ridley SO, Dendy A. Report on the Monaxonida collected by H.M.S. Challenger during the years 1873-1876. Report on the scientific results of the voyage of HMS 'Challenger', 1873-1876. Zoology. 1887;20:1-275 pls 1-51.

Riehl T, Wilson GDF, Malyutina MV. Urstylidae - a new family of abyssal isopods (Crustacea: Asellota) and its phylogenetic implications. Zool J Linnean Soc. 2014;170:245-96.

Ritchie J. Hydrozoa (Hydroid Zoophytes and Stylasterina) of the "Thetis" expedition. Aust Mus Mem. 1911:4:207-869 pls 84-89.

Rogacheva A, Gebruk A, Alt CHS. Holothuroidea of the Charlie Gibbs fracture zone area, northern Mid-Atlantic Ridge. Mar Biol Res. 2013;9:587-623.

Roper CFE, Jereb P. Family Mastigoteuthidae. In: Jereb P, Roper CFE, editors. Cephalopods of the world an annotated and illustrated catalogue of cephalopod species known to date volume 2 Myopsid and Oegopsid squids FAO species catalogue for fishery purposes no 4, vol. 2. Rome: FAO; 2010.

Ross EJ. Satellite to seafloor - the global biogeography of the Elasipodid holothurians. Southampton: University of Southampton; 2012.

Rowe FWE, O'Hara TD, Bardsley TM. Class Holothuroidea. In: Byrne M, O'Hara TD editors. Australian echinoderms: biology, ecology and evolution. Melbourne and Canberra: CSIRO Publishing and ABRS; 2017.

Sanamyan KE, Sanamyan NP. Some benthic Tunicata from the southern IndoPacific Ocean. J Nat Hist. 1999:33:1835-76.

Seiter K, Hensen C, Schroter J, Zabel M. Organic carbon content in surface sediments - defining regional provinces. Deep Sea Res I. 2004;51:2001-26.

Simon-Lledó E, Bett BJ, Huvenne VAl, Schoening T, Benoist NMA, Jones DOB. Ecology of a polymetallic nodule occurrence gradient: implications for deepsea mining. Limnol Oceanogr. 2019;64:1883-94.

Sinniger F, Ocaña OV, Baco AR. Diversity of Zoanthids (Anthozoa: Hexacorallia) on Hawaiian Seamounts: description of the Hawaiian Gold Coral and additional Zoanthids. PLoS One. 2013:8:e52607.

Smith CR, Glover AG, Treude T, Higgs ND, Amon DJ. Whale-Fall Ecosystems: recent insights into ecology, paleoecology, and evolution. Annu Rev Ecol Syst. 2015;7:571-96.

Sorokin SJ, Williams A, Althaus F, Tanner JE. Deepwater sponges (Porifera) of the Great Australian Bight. Project 3.1 - Great Australian Bight benthic biodiversity characterisation. Great Australian Bight Research Program; 2017.

Sulak KJ. The systematics and biology of Bathypterois (Pisces, Chlorophthalmidae) with a revised classification of benthic myctophiform fishes. Galathea Rep. 1977;14:49-108.

Tanner JE, Althaus F, Sorokin SJ, Williams A. Benthic biogeographic patterns in the southern Australian deep sea: do historical museum records accord with recent systematic, but spatially limited, survey data? Ecol Evol. 2018;8:11423-33.

Thubaut J, Puillandre N, Faure B, Cruaud C, Samadi S. The contrasted evolutionary fates of deep-sea chemosynthetic mussels (Bivalvia, Bathymodiolinae). Ecol Evol. 2013;3:4748-66.

Tilburg CE, Hurlburt HE, O'Brien JJ, Shriver JF. The dynamics of the east Australian current system: the Tasman front, the East Auckland current, and the east cape current. J Phys Oceanogr. 2001;31:2917-43.

Tittensor DP, Mora C, Jetz W, Lotze HK, Ricard D, Vanden Berghe E, et al. Global patterns and predictors of marine biodiversity across taxa. Nature. 2010;466: 1098-103.

Tomczak M, Godfrey JS. Regional oceanography: an introduction. Delhi: Daya Publishing House; 2003.

Vecchione M, Young RE, Roper CFE. 2013. Heteroteuthis dagamensis Robson 1924. Version 03 November 2013 (under construction). http://tolweb.org/ Heteroteuthis_dagamensis/20053/2013.11.03.

Vervoort W, Watson JE. Marine Fauna of New Zealand. Leptothecata (Cnidaria: Hydrozoa) (Thecate hydroids). NIWA Biodivers Mem. 2003;119:1-538.
Watson JE. Pearson Island expedition, 1969 - hydroids. Trans Roy Soc S Aust. 1973:97:153-200.

Watson JE. Some hydroids (Cnidaria, Hydrozoa) from the Great Australian Bight in the collection of the South Australian Museum. Zootaxa. 2018:4410:1-34.

Watson JE. Bathyal and abyssal hydroids (Hydrozoa, Leptothecata) from SouthEastern Australia. Mem Mus Vic. 2019;78:65-72.

Williams A, Althaus F, Maclntosh H, Loo M, Gowlett-Holmes K, Tanner JE, et al. Characterising the invertebrate megafaunal assemblages of a deep-sea (200$3000 \mathrm{~m}$ ) frontier region for oil and gas exploration: the Great Australian Bight, Australia. Deep Sea Res II. 2018a;157-158:78-91.

Williams A, Althaus F, Pogonoski JJ, Osterhage D, Gomon M, Graham K, et al. Composition, diversity and biogeographic affinities of the deep-sea (200$3000 \mathrm{~m}$ ) fish assemblage in the Great Australian Bight, Australia. Deep Sea Res II. 2018b;157-158:92-105.

Witbaard R, Duineveld GCA, Kok A, van der Weele J, Berghuis EM. The response of Oneirophanta mutabilis (Holothuroidea) to the seasonal deposition of phytopigments at the porcupine abyssal plain in the Northeast Atlantic. Prog Oceanogr. 2001;50:423-41.

Woolley SNC, Tittensor DP, Dunstan PK, Guillera-Arroita G, Lahoz-Monfort JJ, Wintle BA, et al. Deep-sea diversity patterns are shaped by energy availability. Nature. 2016;533:393-6.

Young PS. A preliminary assessment of the characters used in the definitions of the subfamilies at present included in the Scalpellidae Pilsbry, 1907 sensu Newman, 1996 (Cirripedia, Thoracica). In: Schram FR, von Vaupel JC, editors Crustaceans and the biodiversity crisis vol 1 Proceedings of the Fourth International Crustacean Congress, Amsterdam, the Netherlands, 20-24 July 1998. Leiden: Brill; 1990.

Young PS. The Scalpellomorpha (Crustacea, Cirripedia), with a list of extant species (except the Calanticidae). Galathea Rep. 2007;21:7-73.

Young REV, 2017. Idioteuthis Sasaki, 1916. Idioteuthis cordiformis (Chun, 1908). http://tolweb.org//dioteuthis_cordiformis/19510/2017.10.10.

Zevina GB. Barnacles of the suborder Lepadomorpha (Cirripedia, Thoracica) of the World Ocean. I. Family Scalpellidae. Leningrad: Zoological Institute, Academy of Sciences of the USSR; 1981

Zhang J, Hutchings P, Burghardt I, Kupriyanova E. Two new species of Sabellariidae (Annelida, Polychaeta) from the abyss of eastern Australia. Zootaxa. 2020:4821:487-510.

Zhang J, Hutchings P, Kupriyanova E. A revision of the genus Petta (Polychaeta Pectinariidae), with two new species from the abyss of south-eastern Australia. Zootaxa. 2019;4614:303-30.

\section{Publisher's Note}

Springer Nature remains neutral with regard to jurisdictional claims in published maps and institutional affiliations.

Ready to submit your research? Choose BMC and benefit from:

- fast, convenient online submission

- thorough peer review by experienced researchers in your field

- rapid publication on acceptance

- support for research data, including large and complex data types

- gold Open Access which fosters wider collaboration and increased citations

- maximum visibility for your research: over $100 \mathrm{M}$ website views per year

At $\mathrm{BMC}$, research is always in progress.

Learn more biomedcentral.com/submission 